\title{
Studies on the Biochemical and Immunological Properties of Human Placental Lactogen (hPL : Human Chorionic Somatomammotropin, hCS)
}

Part II. Biochemical Properties of hPL (hCS)

\section{Hajime MORIKAWA}

Department of Obstetrics and Gynecology Kobe University, School of Medicine Ikutaku, Kobe 650, Japan (Director : Professor Shimpei Tojo, M.D.)

In this paper the author describes the biochemical and physicochemical properties of hPL-Kobe which was purified by the author and reported in the previous manuscript.

HPL-Kobe was a simple protein with the maximum absorption in the ultraviolet region at $278 \mathrm{~m} \mu$ and with the minimum at $257 \mathrm{~m} \mu$.

The tyrosine/tryptophan ratio was 3.26 .

Using the Orcinol sulfuric acid method, carbohydrates were not detected, and analysis of amino acid content with Moore and Stein's method revealed that it contained asparate and glutamate remarkably. These findings resembled those of Li's hGH.

With the Archibald method ultracentrifugal analysis of hPL-Kobe in $5 \mathrm{M}$ guanidine hydrochloride or $8 \mathrm{M}$ urea revealed a single peak with a molecular weight between 25000 and 26500 , but in $0.2 \mathrm{M}$, sodium chloride did not reveal a homogeneous precipitation pattern because of its suspected aggregation.

Tryptophan residues were not estimated in acetate buffer, but absorption spectrum of the hPL treated with N-bromosuccinimide in $5 \mathrm{M}$ urea indicated tryptophan was present at $0.97 \%$. These results suggest that tryptophan residues might be important in stabilizing the conformation of the protein by hydrophobic interactions with other nonpolar residues.

Free $\mathrm{SH}$ residues and hystidine residues were not detected in the hPL and one or two disulfide bonds were estimated in each molecule.

Compared the native hPL, reduced and carboxymethylated hPL was eluted only in a small retarded fraction on sephadex G-75 gel filtration, and its immunological and biological activities markedly decreased.

It appears likely, therefore, that hPL is a kind of one chain peptides with a flat form, and its interactions responsible for the teritiary structure are essentially independent of the disulfide bridge, which is suspectedly important for hormone activities and stabilization of hPL.

The $\mathrm{NH}_{2}$-terminal amino acid of hPL-Kobe was valine, and after the treatment with LAP or crude urea (it is considered as the action of contaminated cyanate) the bio- 
logical activity of it disappeared completely, but the immunological was not altered. Therefore, it is considered that the fragments with biological activity may exist on the $\mathrm{N}$-terminal and the immunological one on the G-terminal of the hPL.

Since the immunological and biological activities were lost after heating or incubation in acidic solution, so hPL-Kobe may be an unstable protein hormone.

(See pp. 1059 1079) 


\title{
ヒト胎盤ラクトーゲン (Human Placental Lactogen: hPL, Human Chorionic Somatomammotropin: hCS) の生化学的ならびに免疫学的性格に関する研究
} 第二編 HPL (hCS) の生化学的性格に関する研究

\author{
神戸大学医学部産科婦人科学教室（主任 東条伸平教授）
}

森川肇

(昭和48年 2 月 21 日受付)

hPL-Kobe は，酸性アミノ酸を主体とする分子量約26,000の単純蛋白体で, tryptophan 含有率は 0.97\%, tyrosine/tryptophan molar ratio は3.26であり, free の SH 残基や histidine 残基は存在せ ず, helix の少い平坦な一鎖ペプタイドであり，三次結合はおそらく S-S 結合であろう. 生物活性は $\mathrm{N}$ 末端に，免疫活性はおそらくG末端に分れて存在すると考えられ，わずかな条件の変化や立体構造の 変化によつても生物, 免疫活性が消失し蛋白体として極めて不安定である.

序論

著者は, 前編においてヒト胎盘から均一な蛋白体として human Placental Lactogen (hPL, human Chorionic Somatomammotropin : hCS) を抽出精製し，てれを hPL-Kobe と名づけて報告した1).

本編においては, その蛋白体としての性格, つまり構成分子, 分子量, 立体構造や蛋白体としての安定性 を検討し，若干の知見を得たので報告する.

\section{I 研究の目的亡計画}

著者は, hPL が精製過程に於いて示す態度から，本物質は pH 9.0 の DEAE-G に密に吸着され，かつ 酸性荷電性の強い性格をもち, しかもセファッデックスG-100ゲル沪過における態度から分子形態が平坦で あるか，あるいは小さいこと，さらには透析操作中に aggregate しやすい性格を持つととなどを報告した。

著者はこの hPL-Kobe を用いて, まずその構成ア々ノ酸及び糖成分を検討し, 分子量, S-S 結合, 遊離 アミノ基， $\mathrm{G}$ 末端及び $\mathrm{N}$ 末端の検討などから，hPL の蛋白体としての大きさと形態をきめ，さらに熱及び $\mathrm{pH}$ 処理により蛋白体としての安定性を検討することとした.

\section{II 実験材料と方法}

\section{A 実 験 材 料}

\section{HPL}

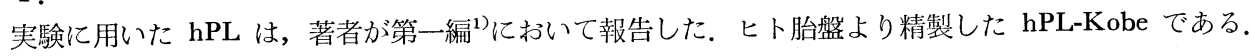

\section{2. 主たる化学薬品}

\section{i Glucose}

糖成分の分析の対称として用いた標準 glucose は, 半井化学薬品株式会社製試薬特級(無水壏)を用いた. ii Pure Urea

半井化学薬品株式会社製試薬特級のものを再結晶させ, さらに Amberlite MB-3 を用いて含有されてい る cyanate などを除去したものを使用した。

iii N-Bromosuccinimide (NBS) 
半井化学薬品株式会社製試薬特級を使用した.

IV グアニジン塩酸

半井化学薬品株式会社製試薬特級を使用した.

v 5, 5'-Dithiobis (2-nitrobenzoic acid) : (DTNB)

半井化学薬品株式会社製試薬特級のものを使用した。

vi 5-amino-1-H-tetrazole (DHT)

東京化成工業株式会社製 DHT $1 \mathrm{~g}$ を，1.6規定塩酸 $23 \mathrm{ml}$ に溶解し，承浴中でゆつくりと $0.7 \mathrm{~g}$ sodium nitrate $/ 10 \mathrm{mlH}_{2} \mathrm{O}$ 溶液を加えてゆき, さらに使用直前に苛性カリを加えて $\mathrm{pH} 5.0$ とした.

VII 2-メルカプトエタノール

半井化学薬品株式会社製特製試薬を使用した.

VIII ロイシンアミノペプチダーゼ (LAP)

SIGMA Chemical Company (U.S.A.) のものにつき, ジイソプロピルフルオリン酸 (DFP) 処理を行つ て混在するプロテアーゼを除去して使用した.

\section{B 実 験 方 法}

\section{1. hPL であることの指標}

S-S 結合やN末端の切断或いは尿素による分子形態の変化, さらには熱, $\mathrm{pH}$ 処理を行つた場合の, hPL の構造の変化と生物活性及び免疫活性の関係を検討する指標として次のものを用いた。

I 生物活性の指標

ラット副辠脂の脂質分解作用を hPL の生物活性の指標とした ${ }^{1)}$.

II 免疫活性の指標

免疫学的には, Ouchterlony 法 ${ }^{2)}$ にり, 抗 hPL 血清に対する交叉性を指標とした. 抗 hPL 血清は, hPLKobe を, 雄成熟モルモットに反復投与して作成し, 正常ヒト血漿粉末による吸収操作を行つた後使用した.

2. 構成要素の分析

1 吸光度の検討

0.05モルトリス塩酸緩衡液 $\mathrm{pH} 8.1$ に, hPL-Kobe $500 \mu \mathrm{g} / \mathrm{ml}$ に溶解し, 波長 $240 \mathrm{~m} \mu$ から $450 \mathrm{~m} \mu$ までの吸光度を，連続分光光度計（島津製作所製）で測定し，吸光度曲線を作成した。

II $ア \Sigma$ 酸成分

構成アミノ酸は，Moore and Stein ${ }^{3)}$ の方法でしらべた。 加水分解には 6 規定塩酸を使用し， $110^{\circ} \mathrm{C} て ゙ 25$ 時間と43洔間加熱する 2 方法を用いた，加水分解終了後は，アミノ酸自動分析装置 (Shibata type AA-600) を用いてアミノ酸分析を行つた。

III トリプトファン含有量

0.1 モル, pH 4.0 acetate buffer 中に, hPL-Kobe を $1 \mathrm{mg} / 3 \mathrm{ml}$ 溶解し, NBS を 0.15 及び $0.3 \mu \mathrm{mol}$ 加えて, 波長 $210 \mathrm{~m} \mu$ から $310 \mathrm{~m} \mu$ までの吸光度曲線をそれぞれ作成し, 波長 $280 \mathrm{~m} \mu$ での吸光度の減少を測定した. また，さらに，同じ緩衡液に 5 モル尿素を加えて hPL-Kobe を溶解し，NBS を0,0.3及び $0.5 \mu \mathrm{mol}$ 加え て吸光度曲線を作成し，波長 $280 \mathrm{~m} \mu$ での吸光度の減少を測定した.

それぞれの波長 $280 \mathrm{~m} \mu$ での吸光度の減少を，Spande and Witkop ${ }^{4)}$ の公式を用いて計算し，hPL-Kobe のトリプトファン含有量を決定した.

IV チロジンートリプトファン比

0.1 規定苛性ソーダ溶液 ( $\mathrm{pH} 12.4)$ ） hPL-Kobe を $1 \mathrm{mg} / 3 \mathrm{ml}$ に溶解し，波長 $250 \mathrm{~m} \mu$ から $300 \mathrm{~m} \mu$ の吸光度曲線を作成した. 波長 $282 \mathrm{~m} \mu$ 及び $292 \mathrm{~m} \mu$ に出現する 2 つのピークの吸光度から, Bencze and Schmid の公式 ${ }^{5)}$ を用いて，チロシシンートリプトファン比を計算した.

$\mathrm{V}$ 糖 成 分

Orcinol 硫酸法により測定し，標準物質としては glucose を用いた。 


\section{3 分子量の検討}

Archibald 法 ${ }^{6}$ そより測定した．溶媒には，0.2モル塩化ナトリウム溶液， 8 モル尿素溶液及び 4 モル塩酸 グアニジン溶液の 3 種を用い, 日立分析用超遠心機 (UCA-1A) で超遠心し, 光学系はシュリレン光学系 （シュリーレン角度70度）を用いた。

I 沈降 係数

溶媒に 4 モル塩酸グアニジンを使用し，hPL 濃度を $0.4 \% ， 0.8 \%$ 及び $1.2 \%$ の 3 種とし，それぞれダブ ルセクターセルで 60000r.p.m. で10C，60分間超遠心し，得られた沈降図形からそれぞれの場合のみかけの 沈降係数 S20w (app.) を計算し, $\mathrm{S} 20 \mathrm{w}(0.4), \mathrm{S} 20 \mathrm{w}(0.8)$ 及び $\mathrm{S} 20 \mathrm{w}(1.2)$ の三点から，沈降係数を決定した.

II 0.2 モ塩化ナトリウム

hPL-Kobe を，0.2モル塩化ナトリウム溶液に1.0\%の濃度に溶解し， $10^{\circ} \mathrm{C}, 60000$ r.p.m. で120分間超遠心 し，その21，46，60，120分後の沈降図形から Archibald 法により分子量を検討した.

III 8 モル尿素溶液

溶媒に 8 モル尿素溶液を使用し，hPL-Kobe 濃度は0.6\%及び1.0\%の 2 種とした。そそれぞれ，合成界面セ ルを用いて超遠心し，初濃度を決定したあと，ダブルセクターセルで, 25090r.p.m., 60分間超遠心し，12分 毎に得られた沈降図形から，0.6\%及び，1.0\%のみかけの分子量, Mapp (0.6), Mapp (1.0) を計算した.

Mapp (0.6) 及び Mapp(1.0)の 2 点から, hPL-Kobe の分子量 M(0) を計算した.

IV 4 モル塩酸グアニジン溶液

溶媒に 4 モル塩酸グアニジン溶液を用いた場合の hPL-Kobe 濃度は，0.4\%，0.8\%及び1.2\%の 3 種とし た。初濃度を決定したあと，0.4\%の場合は 25090r.p.m. で，0.8\%の場合は 16880r.p,m. で，1.2\%の場合 は 15590r.p.m. で10 C，60分間超遠心し，12分毎に得た沈降図形からそれぞれみかけの分子量，Mapp (0.4), Mapp (0.8) 及び Mapp (1.2) を計算しての 3 点から hPL-Kobe の分子量 M(0) を計算した.

\section{4. 立体構造の検討}

I $\mathrm{SH}$ 残基

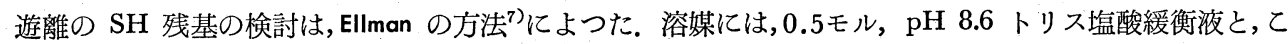
の溶液に pure urea 5 モルの濃度に溶解した溶液の 2 種を用いた。 hPL-Kobe の濃度を $1 \mathrm{mg} / \mathrm{ml}$ とし, DTNB $0.2 \mathrm{ml}$ 加えて, 波長 $350 \mathrm{~m} \mu$ から $450 \mathrm{~m} \mu$ までの吸光度曲線を作成した. DTNB と SH 残基の 反応による p-nitrophenol の吸光度（波長 $412 \mathrm{~m} \mu$ ）から，hPL1モル当りの SH 残基のモル濃度を求めた。

II ヒスチジン残基

遊離のヒスチジン残基は，Horinishi の方法8) とより測定した。溶媒には，0.67モル bicarbonate buffer と， $0.1 モ ル ， \mathrm{pH} 8.6$ トリス緩衡液に pure urea を 5 モル濃度に溶解した 2 種を用い，hPL-Kobe 濃度は $1 \mathrm{mg} /$ $3 \mathrm{ml}$ とした。.まず0.67モル bicarbonate buffer の場合には，DHT 溶液を $10 \mu 1$ 加光，20分及び40分後 の波長 $480 \mathrm{~m} \mu$ での吸光度を, また 5 モル尿素溶液の場合には DHT 溶液を $25 \mu 1,50 \mu 1,75 \mu 1$ 及び $175 \mu 1$ 加えて40分後の $480 \mathrm{~m} \mu$ での吸光度を測定した。、いずれの場合も DHT を加えて生ずる.

histidine-bisazo-1-H-tetrazole の $480 \mathrm{~m} \mu$ での吸光度から histidine 残基を求めた.

III 分子形態中の S-S 結合とその切断

hPL-Kobe を， 8 モル尿素溶液と 1 モル及び 2 モル塩酸グアニジン溶液とインキュベーションして S-S 結合を切断し，DTNB を加えて，切断されて生じた SH 残基と DTNB が反応する割合から，分子内 SH 残基を測定した。

まず 8 モル， pure urea, 0.01 モル EDTA, 0.05 モルトリス緩衡液に，hPL-Kobe 0.84mg を溶解し， DTNB $0.2 \mathrm{ml}$ 加えて, 30分インキュベーションした. インキュベーション前後の, $412 \mathrm{~m} \mu$ での吸光度

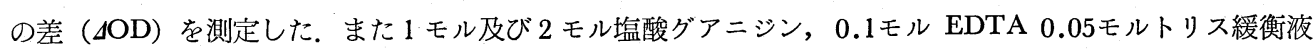

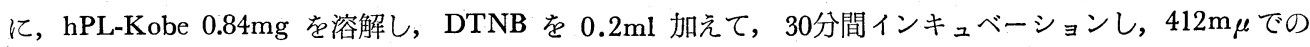
$\triangle \mathrm{OD}$ を測定した。それれぞれの場合の hPL1モル当りの分子内 $\mathrm{SH}$ 残基モル濃度 $(\mathrm{S})$ は，それぞれの $4 \mathrm{OD}$ 
1062 ヒト胎盤ラクトーゲン (Huma Placental Lactogen: hPL' Human Ghorionic

Somatomammotropin: hCS) の生化学的ならびに免疫学的性格に関する研究（森川）

から次の公式を用いて計算した。

$$
\mathrm{S}=\frac{\Delta \mathrm{OD} \times \mathrm{K} \times \mathrm{V}}{\mathrm{H}}
$$

$\triangle \mathrm{OD}: \mathrm{DTNB}$ 添加前後の波長 $412 \mathrm{~m} \mu$ での吸光度の差

$\mathrm{K}$ : 切断された S-S 結合と DTNB との化合物の分子吸光係数 $=\frac{1}{1.36 \times 10^{4}}$

$\mathrm{V}:$ 反応全溶液量 $=3(\mathrm{ml})$

$\mathrm{H}$ : 用いた hPL-Kobe の量 (ミリモル). 分子量を 25000 として計算した.

$$
\mathrm{H} \doteqdot 3.23 \times 10^{-5}
$$

分子中の S-S 結合の切断は，まず多量のメルカプトエタノールで hPL 分子中の S-S 結合を還元し，遊離 した SH 残基が空気中の酸素により容易に酸化され再び S-S 結合となるのを防ぐため，モノョード酶酸を 用いて SH 残基を保護した。即ち密栓遮光できる容器に，0.5モル pH 5.6 トリス緩衡液 $1 \mathrm{ml}$ と pure urea 10 モル溶液に EDTA $0.2 \%$ を溶解したもの $8 \mathrm{ml}$ を入れ，てれにメルカプトエタノール $0.1 \mathrm{ml}$ を加え， その $\mathrm{pH}$ を 2 規定塩酸又は10規定苛性ソーダ溶液で $\mathrm{pH} 8.6$ 亿調整した. これに hPL-Kobe $5 \mathrm{mg}$ を加え， 密栓遮光後器内を連続的に窒素ガスで飽和状態となるようにし， $22-25^{\circ} \mathrm{C} て ゙ ~ 4$ 時間攪拌，次いで容器を完全 に遮光したまま, モノヨード酢酸 $0.268 \mathrm{~g}$ を 1 規定苛性ソーダ溶液 $1 \mathrm{ml}$ 亿溶解したものを少量ずつ加えて ゆき， $\mathrm{pH}$ を 8.0 以上としたあと，15分間反応させ， 5 \%酶酸溶液を加えて $\mathrm{pH} 4.0$ として反応を停止させ た. セファデックスG-75カラム $(1 \mathrm{~cm} \times 20 \mathrm{~cm})$ を $5 \%$ 酶酸溶液で平衡とし, 遮光しつつ反応終了液を上端 に添加し， 5 \%酶酸溶液でゲル沪過を行つた. 溶出液を $1 \mathrm{ml}$ ずつプールし, $278 \mathrm{~m} \mu$ での吸光度を測定し て吸光度曲線を作成した。

また， native hPL-Kobe $5 \mathrm{mg}$ を反応終了液と同量の 5 \%酶酸溶液に溶解し，七ファデックスG-75でゲ ル沪過して吸光度曲線を作成し，コントロールとした。

IV N末端の分析

ロイシンアミノペプチダーゼ (LAP) により hPL-Kobe のN末端を切断した，基質として使用する hPL-

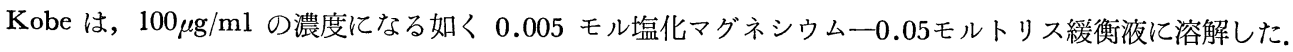
LAP は, $4 \mu \mathrm{g}$ 及び $40 \mu \mathrm{g} の 2$ 種とし, インキュベーション時間はそれぞれ 3 時間， 8 時間，12時間とした。 反応終了後は氷酰酸により $\mathrm{pH} 4.0$ として反応を停止させ, 各インキュベーション溶液中の遊離アミノ酸を アミノ酸自動分析装置で測定した。

\section{5. 立体構造亡生物学的並びに免疫学的活性との関係}

I. N末端と生物活生の関係

前述した方法でN末端を切断したそれぞれの hPL-Kobe の生物活性を，ラット副睪脂の脂質分解作用で 検討した。

II. N末端と免疫活性の関係

前述した方法でN末端を切断した hPL-Kobe の抗 hPL 血清に 対する免度学的交叉性を, Ouchterlony 法で検討した。

III S-S 結合と生物活性の関係

前述した如く，メルカプトエタノールで，S-S 結合を還元し，モノヨード酶酸で SH 残基を保護したあ と，セファデックス G-75 でゲル沪過を行つた hPL につき，脂質分解作用を検討した.

IV S-S 結合と免度活性の関係

S-S 結合を切断し, carboxymethylation を行つた hPL の抗 hPL 血清に対する免疫学的交叉性を Ouchterlony 法で検討した。

V HPL の生物, 免疫両活性に及ぼす尿素の影響

用いた尿素は，市販試薬特級の尿素，同尿素を再結晶したもの及び純化尿素の 3 種とし， pH 7.4 の酶酸 
アンモニウム緩衡液にそれぞれ 2 モル， 6 モル， 8 モルの濃度に溶解し，ついで hPL-Kobe を $100 \mu \mathrm{g} / \mathrm{ml}$ の割合に加えたあと， $37^{\circ} \mathrm{C} て ゙ 1$ 時間及び 6 時間インキュベーションし，それぞれの生物活性を脂質分解作用 から, 免疫活性を抗 hPL 血清に対する交叉性から検討した。

\section{6 安定性に関する検討}

I . 熱佂対する安定性

熱位する安定性は，hPL-Kobe を $1 \mathrm{mg} / \mathrm{ml}$ の割合で，0.05モル， $\mathrm{pH} 7.6$ リン酸緩衡液に溶解した

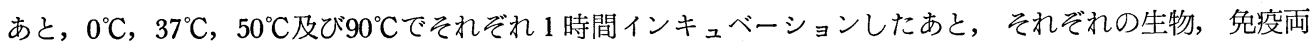
活性を検討した。

II 酸, 塩基に対する安定性

酸，塩基に対する安定性は，hPL-Kobe を $\mathrm{pH} 2.0 ４ .0,8.0$ 及10.0の溶液に $1 \mathrm{mg} / \mathrm{ml}$ の割合に溶解し, $37^{\circ} \mathrm{C}, 1$ 時間インキュベーションしたあと,それぞれの生物, 免疫両活性を検討した.

\section{III 実 験 成 績}

\section{A 構成要素の分析}

\section{1. 吸光度の検討}

hPL-Kobe の吸光度曲線は, Fig. 1 亿示す如くで, $257 \mathrm{~m} \mu$ 亿最少吸光を, $278 \mathrm{~m} \mu$ 亿最大吸光を示した.

\section{2.アミノ酸成分}

アミノ酸分析の結果を Table 1 亿示す. asparate, glutamate などの酸性アミノ酸の含有がきわめめて多 く, cystine の含有は少なかつた.

\section{3.トリプトファン含有量}

トリプトファン含有量の検討では，まず0.1モル acetate buffer 中の native hPL では, Fig. 2 の如く NBS とトリプトファン残基の反応を認めなかつた。

一方，5モル尿素処理を行つた hPL では，Fig. 3 の 如く NBS とトリプトファン残基の反応が起り，280 $\mathrm{m} \mu$ での吸光度が減少し, Spande and Witkop の公 式から，トリプトファン含有率は $0.97 \%$ と計算され た.

\section{4. チロジンートリプトファン比}

$\mathrm{pH} 12.4$ の溶液中での hPL-Kobe の吸光度曲線 は，Fig. 4 に示す如くであつた。 チロジン残基のイオ ン化による最大吸光は, $275 \mathrm{~m} \mu$ 亿変位し, Bencze and Schmidの公式からチロジンートリプトファンの molar ratio は3.26であつた。

\section{5. 糖 成 分}

分析結果は, Table 2 の如くであり, 糖成分は認め
Fig. 1. Absorption spectrum of hPL-Kobe hPL-Kobe $270 \mu \mathrm{g} / \mathrm{ml}$ $0.05 \mathrm{M}$ tris buffer $\mathrm{PH} 8.1$

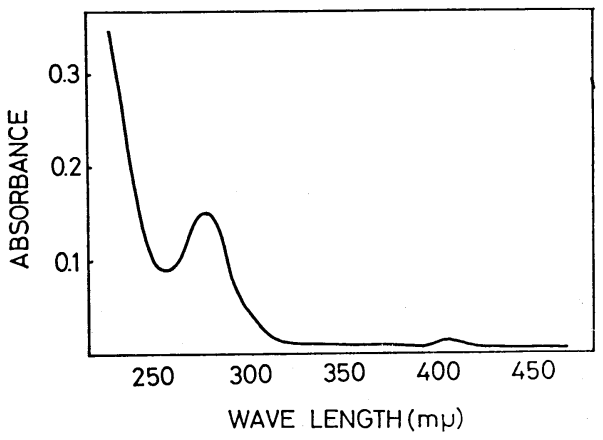
られなかつた。

\section{B 分子量の検討}

\section{1. 沈降係数}

$\mathrm{S}_{20 \mathrm{w}(0.4)}=2.114, \mathrm{~S}_{20 \mathrm{w}(0.8)}=2.090$ 及び $\mathrm{S}_{20 \mathrm{w}(1.2)}=2.092$ が沈降図形から計算され, ての三点から $\mathrm{S}_{20 \mathrm{w}(\mathrm{app})}$ $=2.121-0.0275 \mathrm{C}\left(\mathrm{C}: \mathrm{hPL}\right.$ 濃度, \%) となり, hPL-Kobe の沈降係数 $\mathrm{S}_{20 \mathrm{w}(0)}$ は2.121 となつた。

\section{2 モル塩化ナトリウム溶液}

溶媒に 0.2 モル塭化ナトリウム溶液を用いた場合の超遠心による沈降パターンは, Fig. 5 の如く, 回転時 間の経過とともに均一ではなくなり, 分子量の検討は不可能であつた. 
1064 ヒト胎盤ラクトーゲン (Human Placental Lactogen: hPL, Human Chorionic Somatomammotropin:hCS) の生化学的ならびに免疫学的性格に関する研究（森川）

Table 1. Amino acid content of hPL

\begin{tabular}{l|r|r}
\hline & \multicolumn{2}{|c}{ hPL-Kobe } \\
\cline { 2 - 3 } & \multicolumn{2}{|c}{ hydrolysis } \\
\cline { 2 - 3 } & $25 \mathrm{hr}$ & $43 \mathrm{hr}$ \\
\hline Lysine & 7.35 & 5.61 \\
Histidine & 5.78 & 5.44 \\
Arginine & 5.87 & 8.33 \\
Aspartate & 15.40 & 15.64 \\
Threonine & 8.10 & 7.14 \\
Serine & 8.74 & 7.14 \\
Glutamate & 12.70 & 11.73 \\
Proline & 4.15 & 5.82 \\
Glycine & 3.72 & 4.08 \\
Alanine & 3.27 & 3.61 \\
Cystine & 0.46 & 0.25 \\
Valine & 3.23 & 3.23 \\
Methionine & 2.02 & 1.74 \\
Isoleucine & 2.52 & 3.61 \\
Leucine & 10.10 & 10.41 \\
Tyrosine & 2.64 & 2.21 \\
Phenylalanine & 3.93 & 3.99 \\
\hline
\end{tabular}

each amino acid residue $(\mu \mathrm{g})$ per total amino acid residues $(\mu \mathrm{g})$

Amino acid content $6 \mathrm{f}$ hPL-Kobe was determined by the Moore and Stein's method.

Fig. 2. Absorption spectra of hPL-Kobe modified with N-bromosuccinimide in acetate buffer $\mathrm{pH} 4.0$

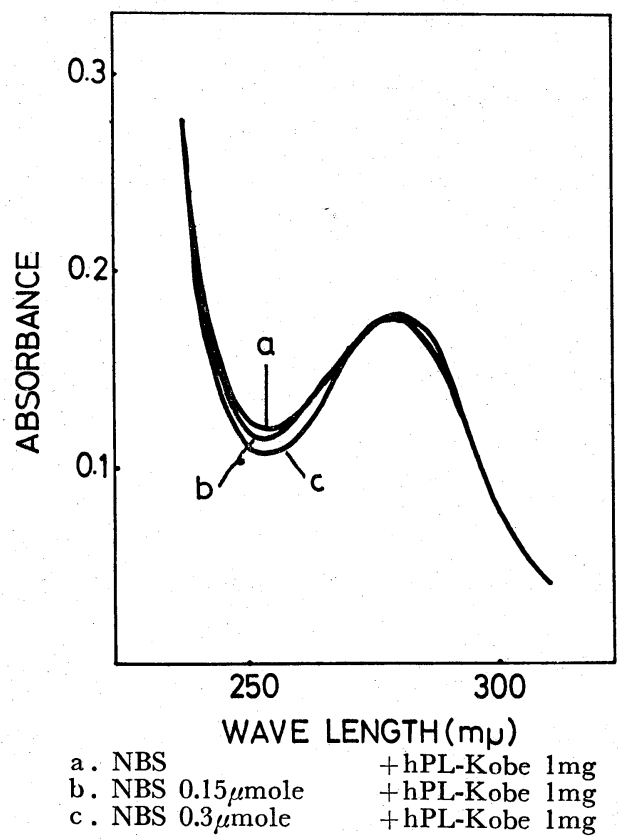

Fig. 3. Absorption spectra of hPL-Kobe modified with N-bromosuccinimide in $5 \mathrm{M}$ urea and acetate buffer $\mathrm{pH} 4.0$

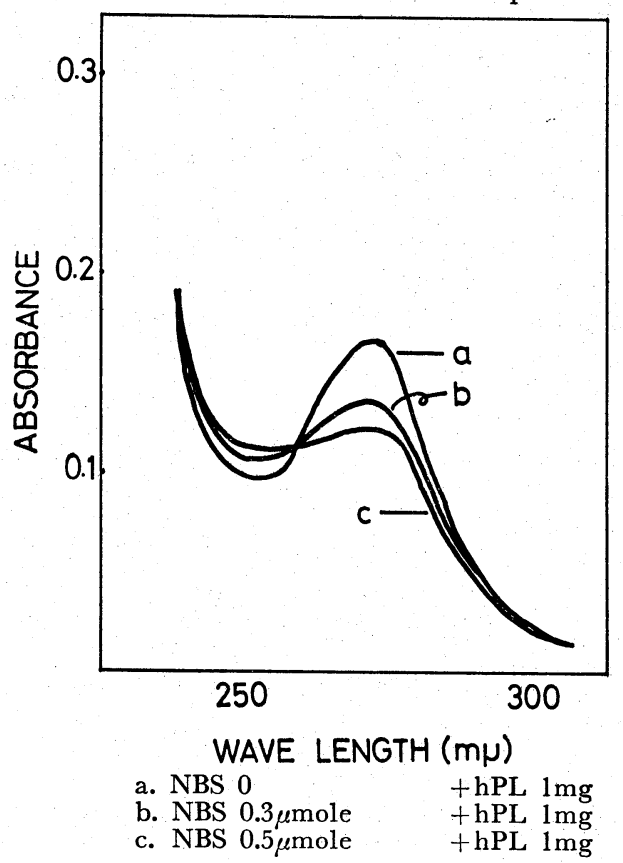




\section{8 モル尿素溶液}

hPL-Kobe の濃度を0.6\%とした場合の超遠心による沈降パターンは, Fig. 6 の如くであり, 左右対称の 一つのピークを示した。合成界面セルを用いて初濃度を決定した後, 沈降図形から0.6\%でのみかけの分子 量を計算したとてろ，Fig.7 の如くであり， $\mathrm{M}_{\mathrm{app}(0.6)}=17358$ となつた. hPL-Kobe の濃度を1.0\%とした 場合の超僖心の沈降パターンは，Fig. 8 の如くであり，みかけの分子量は Fig. 9 の如くであり． $\mathbf{M}_{\mathrm{app}(1.0)}$ =11260となつた.

$M_{\mathrm{app}(0.6)}$ と $\mathrm{M}_{\mathrm{app(1.0)}}$ の二点から, hPL の分子量を計算すると, Fig. 10 の如く, $\mathrm{M}_{(0)}=26505$ となつた.

\section{4 モル塩酸グアニジン溶液}

hPL-Kobe の濃度を0.4\%とした場合の超遠心による沈降パターンは, Fig. 11 の如くとなり, 左右対称 の一つのピークを示した. $0.4 \%$ の，みかけの分子量は沈降図形から計算して，Fig. 12 の如くであり， $\mathrm{M}_{\mathrm{app}(0.4)}=24343$ となつた.

hPL-Kobe の濃度を $0.8 \%$ とした場合には沈降パタ ーンは, Fig. 13の如くとなり,みかけの分子量は, Fig. 14 の如く計算され, $\mathrm{M}_{\mathrm{app}}(0.8)=26660$ となつた。

hPL-Kobe の濃度を $1.2 \%$ とした場合には，沈降パ ターンは, Fig. 15 の如くとなり, みかけの分子量は, Fig. 16 の如く計算され， $\mathrm{M}_{\mathrm{app}(1.2)}=24498$ となつた.

以上の $M_{\mathrm{app}(0.4)}, \mathrm{M}_{\mathrm{app}(0.8)}$ 及び $\mathrm{M}_{\mathrm{app}(1.2)}$ の三点か ら, hPL-Kobe の分子量 $\mathrm{M}_{(0)}$ は, Fig. 17 の如く, 25012となつた。

\section{C 立体構造の検討}

\section{1. $\mathrm{SH}$ 残基}

$0.5 モ ル ト リ ス$ 塩酸緩衡液中の native hPL 及び 5 モル尿素処理後の hPL にそれぞれ，DTNB を加えた 場合の吸光度曲線は，それぞれ，Fig. 18, Fig. 19 の如くであつた. DTNB と $\mathrm{SH}$ 残基の反応による $412 \mathrm{~m} \mu$ の吸光度の増加が認められず, 遊離の $\mathrm{SH}$ 残 基は存在しなかつた。

Fig. 4. Absorption spectrum of hPL-Kobe at $\mathrm{pH} 12.4$

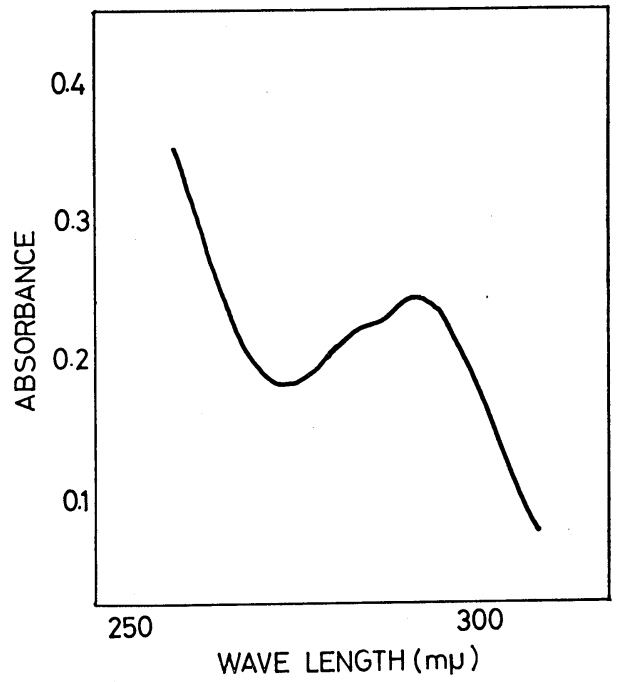

\section{2.ヒスチジン残基}

native hPL 及び 5 モル尿素処理 hPL 亿HT を 加气た場合の吸光度曲線は，Fig. 20 の如くであつた. DHT とヒスチジン残基の反応による $480 \mathrm{~m} \mu$ の吸 光度の増加は認められず, 遊離のヒスチジン残基は存在しなかつた.

\section{3. 分子中の S-S 結合とその切断}

8 モル尿素， 1 モル及び 2 モル塩酸グアニジンを用いて $\mathrm{hPL}$ 分子内の $\mathrm{S}-\mathrm{S}$ 結合を切断して $\mathrm{SH}$ 基とし， DTNB を作用させて, $412 \mathrm{~m} \mu$ での吸光度の差から, 分子内 $\mathrm{SH}$ 基を検討した成績は, Fig. 21 の如くであ り, $\mathrm{SH}$ 基として hPL 1 分子中 2 ケであるととが判明した. S-S 結合をメルカプトエタノールで切断し, carboxymethylation を行つたあと，セファデックス G-75でゲル沪過を行つた成績を，Fig. 22 に示す. denatured hPL(B) は, 対称の native hPL(A) に比し遅れて溶出してはいるが, ただ一つのピークのみを 示している.

\section{4. $N$ 末端の分析}

DFP 処理を行つて純化した LAP と hPL をインキュベーションし，N末端の切断を行つたとてろ，遊 離アミノ酸として valine が検出された.

\section{D 立体構造と生物学的並びに免疫学的活性との関係}


Table 2. Carbohydrate contents of hPL determined with orcinol sulflic acid method

\begin{tabular}{c|c|c}
\hline & $540 \mathrm{~m} \mu$ & $\mathrm{g} / 100 \mathrm{~g}$ \\
\hline crude hPL & 0.005 & 0.3 \\
purified hPL (hPL-KOBE) & 0.001 & 0 \\
\hline
\end{tabular}

Fig. 5. Precipitation pattern of purified hPL on ultracentrifugation

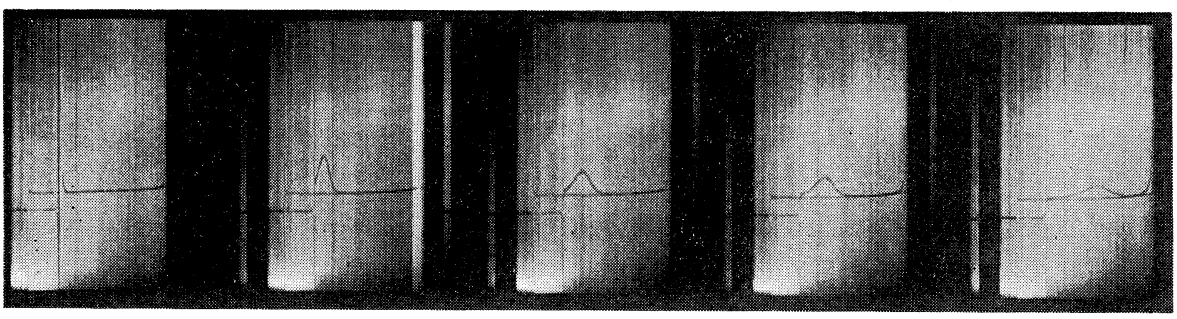

hPL $1.0 \%, 0.2 \mathrm{M} \mathrm{NaCl}, 60000$ r.p.m., $10^{\circ} \mathrm{C}$

Fig. 6. Precipitation pattern of purified hPL on ultracentrifugation $\left(10^{\circ} \mathrm{C}\right)$

(1)

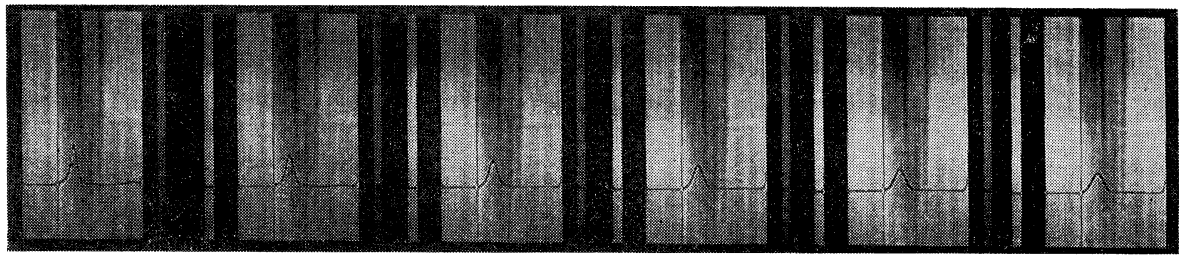

(2)

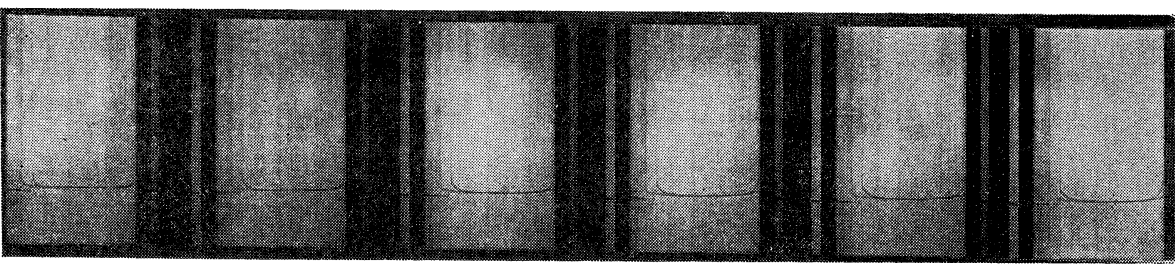

1 hPL 0.6\%, 8M Urea, 12290 r.p.m.

2 hPL $0.6 \%$, 8M Urea, 25090 r.p.m.

\section{1. $\mathrm{N}$ 末端と生物活性の関係}

LAP によるN末端切断を行つた hPL-Kobe の脂質分解作用は，Table 3 に示す如くである，hPL に LAP $4 \mu \mathrm{g} / \mathrm{ml}$ を加えた時には， 8 時間のインキュベーションで，また LAP $40 \mu \mathrm{g} / \mathrm{ml}$ を加えた時には 3 時 間で, hPL-Kobe の脂質分解作用は消失した.

2. $\mathrm{N}$ 末端亡免疫活性の関係

LAP によりN末端を切断された hPL-Kobe の抗 hPL 血清に対する免疫学的交叉性を検討した成績を Fig. 23 に示す. LAP $40 \mu \mathrm{g} / \mathrm{ml}$ の濃度で, 12時間インキュベーションしてもなお抗 $\mathrm{hPL}$ 血清に対する hPL の交攴性は存在した。

\section{S-S 結合と生物活性の関係}

S-S 結合を切断された denatured hPL-Kobe はFig. 22 の如く, native hPL よりもやや遅れて溶出さ れたが，その脂質分解作用は Table 4 の如くであり，生物活性は消失していた.

4. S-S 結合之免疫活性の関係

S-S 結合を切断した hPL-Kobe の抗 hPL 血清に対する反応を Fig. 24 に示す. 
Fig. 7. Molecular weight of hPL-Kobe

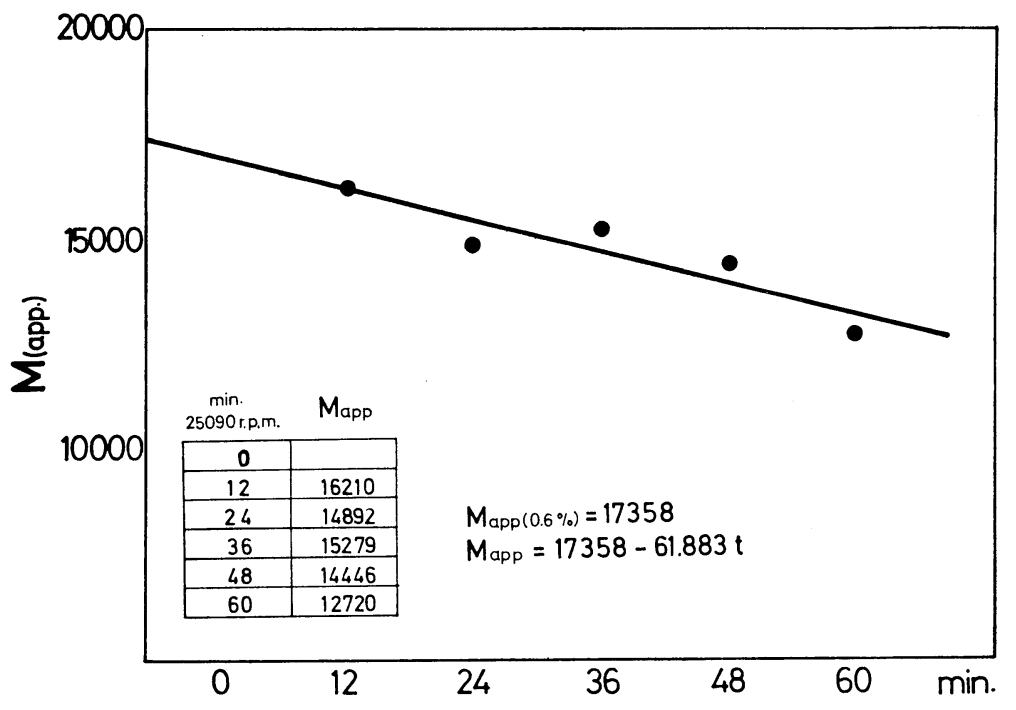

$0.6 \%$ hPL-Kobe in $8 \mathrm{M}$ urea, 25090 r.p.m., $10^{\circ} \mathrm{C}, 60 \mathrm{~min}$.

Fig. 8. Precipitation pattern of purified hPL on ultracentrifugation $\left(10^{\circ} \mathrm{C}\right)$

(1)

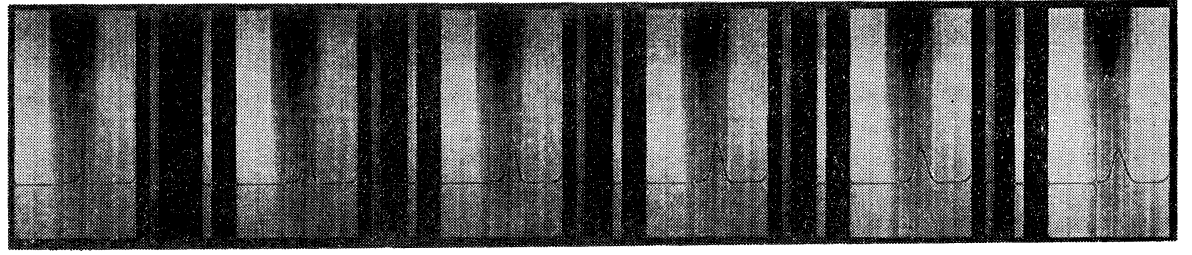

(2)

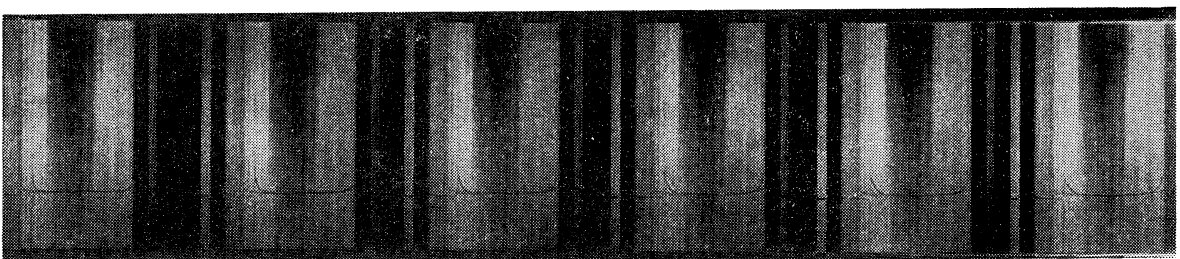

1 hPL $1.0 \%$, 8M Urea, 9690 r.p.m.

2 hPL 1.0\%, 8M Urea, 25090 r.p.m.

hPL-Kobe の抗 hPL 血清に対する免疫学的交叉性は, 消失していた.

\section{HPL の生物, 免疫両活性に及ぼす尿素の影響}

hPL-Kobe を各種尿素とインキュベーションした場合の脂質分解作用を検討した成績を Table 5 亿示す. 市販尿素及び再結晶尿素とのインキューベションで, hPL-Kobe の脂質分解作用は消失したが, 純化尿素 との, インキュベーションを行つてもその脂質分解作用は保たれていた.

hPL-Kobe と各種尿素のインキュベーション後の抗 hPL 血清に対する反応は，Fig. 25 に示す如くであ り，いずれも抗 hPL 血清に対して明瞭な沈降線を示した.

\section{E 安定性に関する検討}

1. 熱に対する安定性 
1068 ヒト胎盤ラクトーゲン (Human Placental Lactogen: hPL, Human Chorionic Somatomammotropin:hCS) の生化学的ならびに免疫学的性格に関する研究（森川）

Fig. 9. Molecular weight of hPL-Kobe

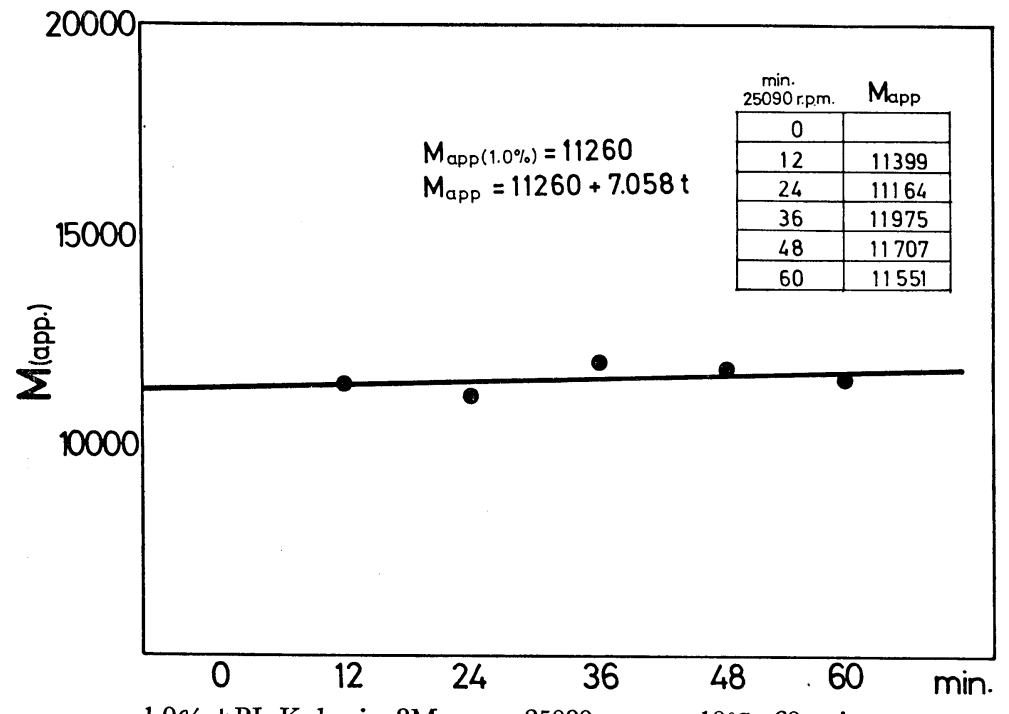

$1.0 \%$ hPL-Kobe in $8 \mathrm{M}$ urea, 25090 r.p.m., $10^{\circ} \mathrm{C}, 60 \mathrm{~min}$.

Fig. 10. Molecular weight of hPL-Kobe in ultracentrifugation

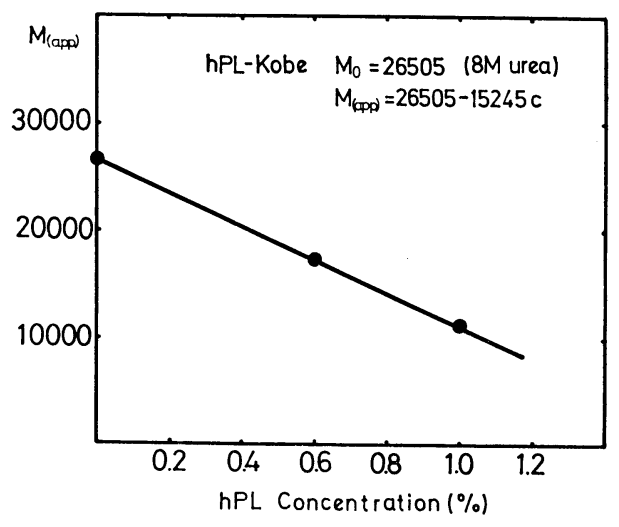

$\mathrm{hPL}$ in $8 \mathrm{M}$ urea

Ultracentrifugation 25090 r.p.m., $10^{\circ} \mathrm{C}, 60 \mathrm{~min}$.
hPL-Kobe を, $0^{\circ} \mathrm{C}, 37^{\circ} \mathrm{C}, 50^{\circ} \mathrm{C}$, 及び $90^{\circ} \mathrm{C}$ でイン ユベーションしたあと, その脂質分解作用を検討した のが, Table 6 である. 即ち $37^{\circ} \mathrm{C}$ でのィンキユベー ションで, hPL-Kobeの最も強い生物活性が認められ

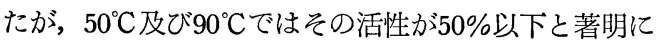
減少した.

また抗 hPL 血清に対する免疫学的交叉性を検討し

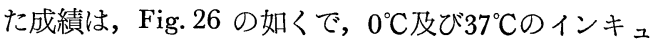

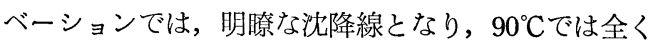
沈降線を認めなかつた。

\section{2. 酸, 塩基に対する安定性}

hPL-Kobe を各種 $\mathrm{pH}$ の溶媒とインキュベーショ ンし，その生物活性 及び免疫活性を検討した成績を Table 7 及び Fig. 27 に示す.

hPL-Kobe は， Table 7 の如く弱アルカリ性で最 も強い脂質分解作用を示し. 酸性溶液中では弱い活性 しか示さなかつた。

一方免疫活性は，Fig. 27 の如くであり，hPL-Kobe はアルカリ性溶液とのインキュベーションでは，抗 hPL 血清に対し明膫な沈降線を示したが，酸性溶液とのインキュベーションでは，沈降線を認めなかつた。

$$
\text { IV 考按 }
$$

すでに著者は, 第一編で hPL の純化精製法につき詳述し，きわめて純度の高い hPL-Kobe を採取し， その精製操作中の態度から hPL は不安定な蛋白ホルモンであることを推察した ${ }^{1)}$. そこでこの hPL-Kobe を用いて, 構成成分, 分子量, 立体構造, 安定性の面から, hPLの蛋白体としての性格を検討した。

まず, hPL-Kobe の吸光曲線は, $278 \mathrm{~m} \mu$ 亿最大吸光を, $257 \mathrm{~m} \mu$ に最小吸光があり, OD280/OD260=1.7 
Fig. 11. Precipitation pattern of purified hPL on ultracentrifugation $\left(10^{\circ} \mathrm{C}\right)$

(1)

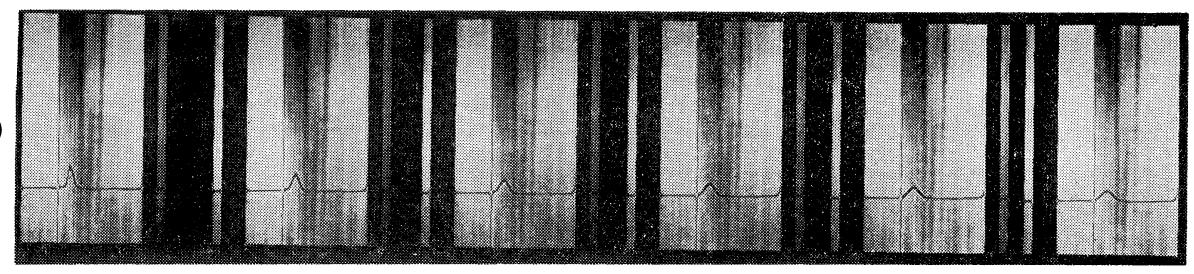

(2)

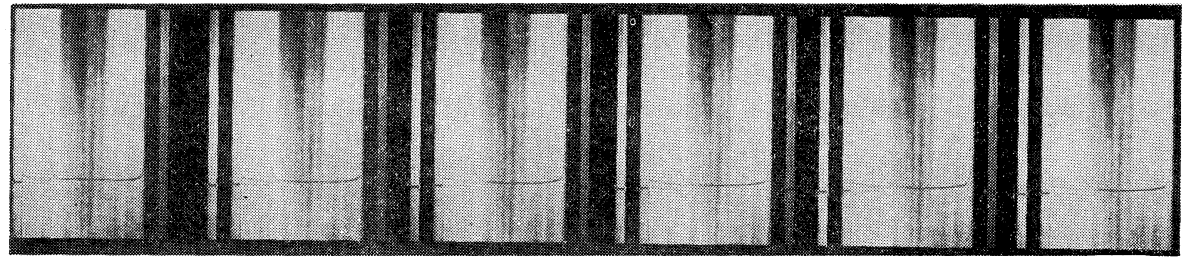

1 hPL 0.4\%, 4M Guanidine-HCl, 9690 r.p.m.

2 hPL 0.4\%, 4M Guanidine-HCl, 25090 r.p.m.

Fig. 12. Molecular weight of hPL-Kobe

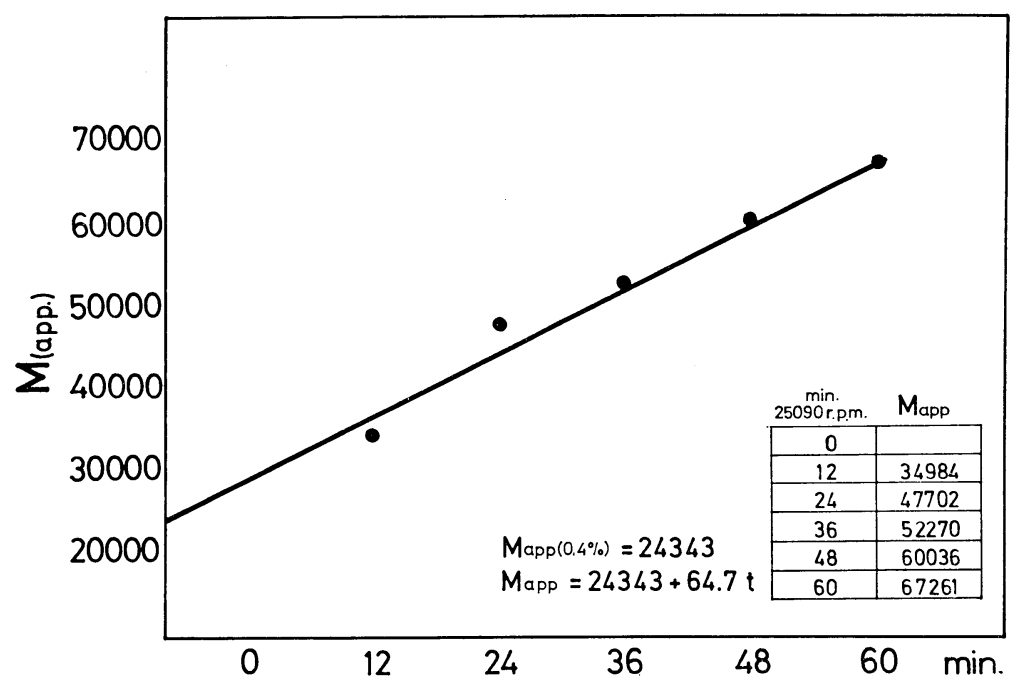

$0.4 \%$ hPL-Kobe in $4 \mathrm{M}$ quanidine-Gl, 25090 r.p.m., $10^{\circ} \mathrm{C}, 60 \mathrm{~min}$.

で，芳香族アミノ酸の存在が認められた。ささらに pH 12.4 の塩基性溶液中では, 吸光曲線はチロジン残基 のイオン化により最大吸光が $275 \mathrm{~m} \mu$ に変位し，チロジンートリプトファン比は， $\mathrm{R}=3.26$ であつた.

Friesen $(1965)^{9)}$ によると, hPL 分子は最大吸光を $278 \mathrm{~m} \mu$ に, 最小吸光を $257 \mathrm{~m}$ に有し, 0.1 規定苛 性ソーダ溶液中の吸光度曲線の変化からチロジンートリプトファン比は， $3 \sim 3.5 て ゙ あ り$, 著者の成績と一 致している.

hPL-Kobe のアミノ酸組成は, 全体的にみると酸性アミノ酸の含有が多いのに反して, シスチンの含有 
Fig. 13. Precipitation pattern of purified hPL on ultracentrifugation $\left(10^{\circ} \mathrm{C}\right)$

(1)

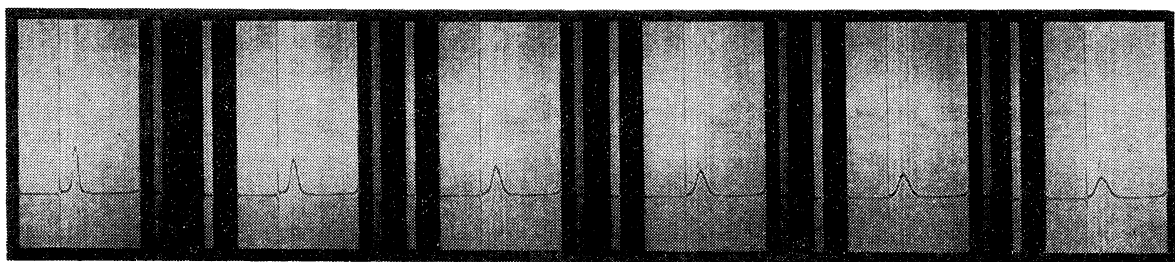

(2)

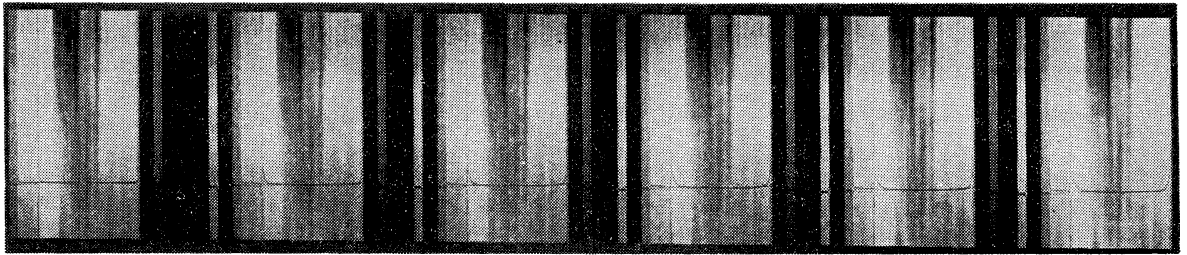

1 hPL $0.8 \%$, 4M Guanidine-HCl, 8950 r.p.m.

2 hPL $0.8 \%$, 4M Guanidine-HCl, 16880 r.p.m.

Fig. 14. Molecular weight of hPL-Kobe

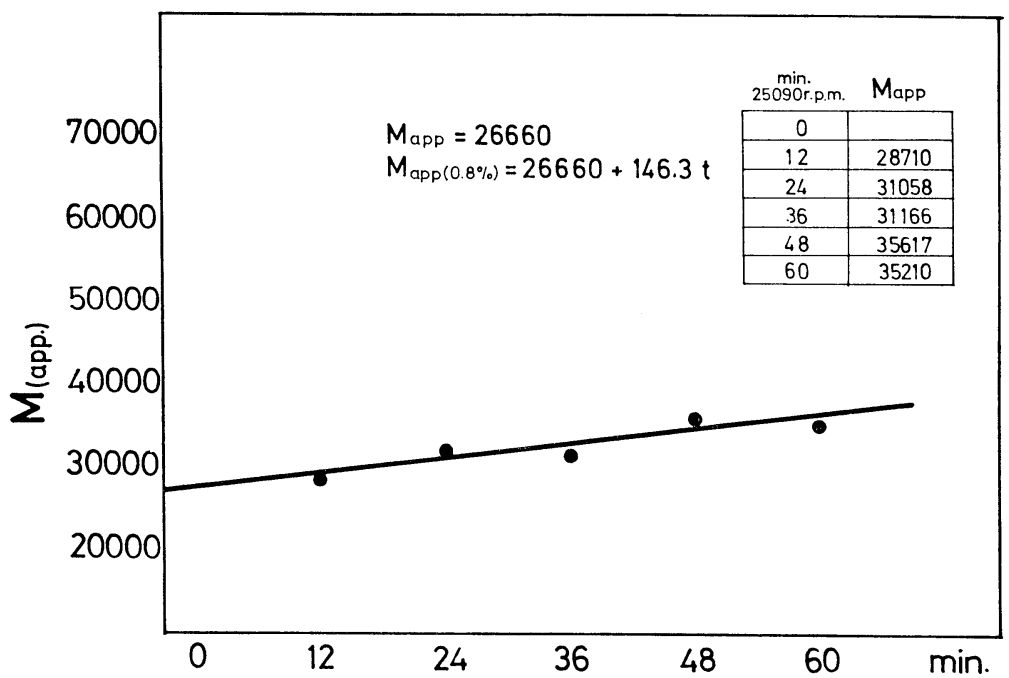

$0.8 \%$ hPLl-Kobe in $4 \mathrm{M}$ guanidine-HGl, 25090 r.p.m., $10^{\circ} \mathrm{C}, 60 \mathrm{~min}$.

量がきわめて少い．また hPL のアミノ酸組成と胎艋より抽出精製したhCG (hG-LH, hC-FSH) ${ }^{10) ~ 12) ~ の そ ~}$ れを比較すると，hC-LH 飞特異的に多く含まれるプロリンの含有量は hPL で少く，全体的な傾向として は hPL と hC-FSH がきわめてよく似ている。一方，hPL では糖成分はまつたく検出されなかつた。

つまり hPL-Kobe は糖を含まない酸性荷電傾向の強い単純蛋白体である.

ところで Florini et al (1966) ${ }^{13)}$ は，hPL は少くととも lipoprotein 或いは glycoprotein ではないと推 察し，著者も hPL が単純蛋白体であることを証明したが，最近の Li et al(1972) ${ }^{14)}$, Niall et al(1971) ${ }^{15)}$ 
Fig. 15. Precipitation pattern of purified hPL on ultracentrifugation $\left(10^{\circ} \mathrm{C}\right)$

(1)

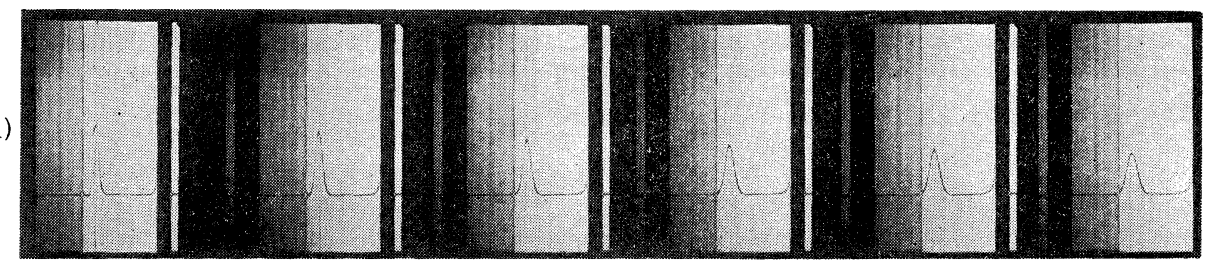

(2)

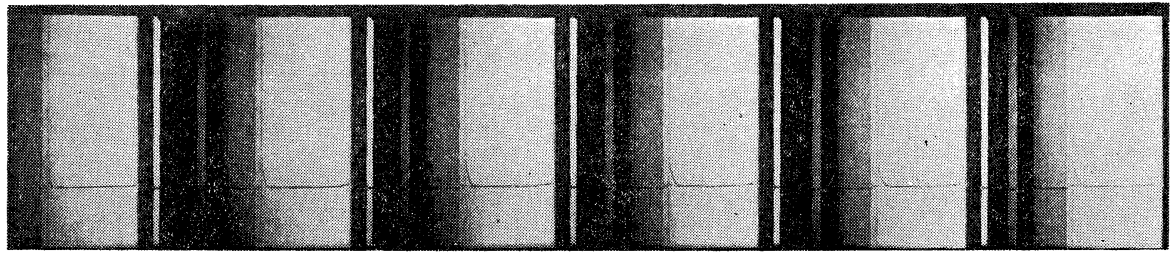

1 hPL 1.2\%, 4M Guanidine-HCl, 8950 r.p.m.

2 hPL 1.2\%, 4M Guanidine-HCl, 15590 r.p.m.

Fig. 16. Molecular weight of hPL-Kobe

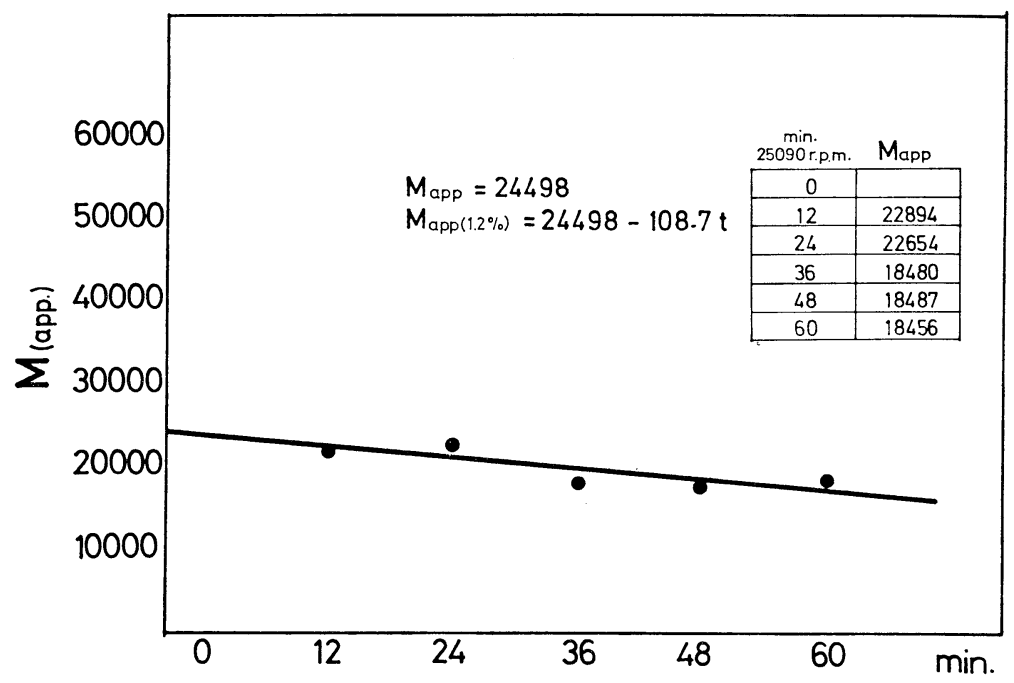

$1.2 \%$ hPL-Kobe in $4 \mathrm{M}$ guanidine-HCl 25090 r.p.m., $10^{\circ} \mathrm{C}, 60 \mathrm{~min}$.

や Neri et al (1972) ${ }^{16)}$ の hGH の amino acid sequence と hPL のそれを比較した報告をみると, hPL は 190 個のアミノ酸連鎖から成り，両者間では85\%の類似性がみられるというが，ての彼等の hPLのアミ ノ酸組成は著者の成績と類似している.

また hPL-Kobe からは未処置の状態ではトリプトファン残基を検出することはできないが， 5 れル尿素 下で hPL に NBS を作用させると，トリプトファンが検出されるようになり，0.97\%程度を含有している ととが判明した.

この様な操作を加えないとトリプトファン残基が検出できないということから，トリプトファン残基は hPL 分子の中にくるまつた形で存在し, hydrophobic bonding 又は non polar amino acid 間の ionic bonding によつて hPL 分子を結合させ，その立体構造を安定化させるような役割をもつようである。 
hPL-Kobe の分子量は，Archibald 法によれば溶媒 に塩化ナトリウム溶液を用いると容易に集合体を作り 均一な沈降像を得ることができなかつたが，尿素溶液 や塩酸グアニジン溶液を buffer として使用すれば, 左右対称な一つのピークの沈降パターンが得られ，約 25000〜26500 という值が得られた. hPL の分子量に ついては, Friesen (1965) 9) はセァデックス G-100 ゲ ル沪過により約 30000 と推定し，一方 Florini $(1966)^{13)}$ は hPL 分子が水素結合で結ばれた二鎖ペプタイドで あり，超遠心により全体としての分子量は 38000 で, 一鎖では 18600 であると述べている，著者も当初 2 鎖 ペプタイドの可能性を示唆したてとがあるが hPL が 容易に集合体を作るととや塩酸グアニジン或いは尿素 を作用させただけではその形態の変化がほとんどない ことなどから，水素結合で結ばれた二鎖のペプタイド であるとは考えにくく，しかも著者の成績では，hPL 分子内 S-S 結合を切断しても分子形態はやや平坦になるのみで分子量の変化が認められなかつたとてろか ら, hPL は分子内に S-S 結合を持つ一鎖ペプタイドであろうと思われる。つまり，Florini は集合体を作 つた hPL を dimer であると考光たために分子量が大きく，一方 Friesen の方法ではセファデックスゲル 沪過の誤差のため hPL の分子量が大きな值となつたと思われ，乙の点を十分に考慮して純化した hPLKobe の分子量が最も罗当性があると考えてよいと思われる.

次に酵素の生物活性に関与すると考无れている SH 残基やヒスチジン残基は，分子の表面に遊離の形 では存在せず，SH 残基は hPLの tertial structure を構成するのにきわめて重要な残基のように思われる.

Fig. 18. Absorption spectra of hPL-Kobe modified with 5,5'-dithiobis (DTNB) in $0.5 \mathrm{M}$ tris buffer $\mathrm{pH} 8.6$

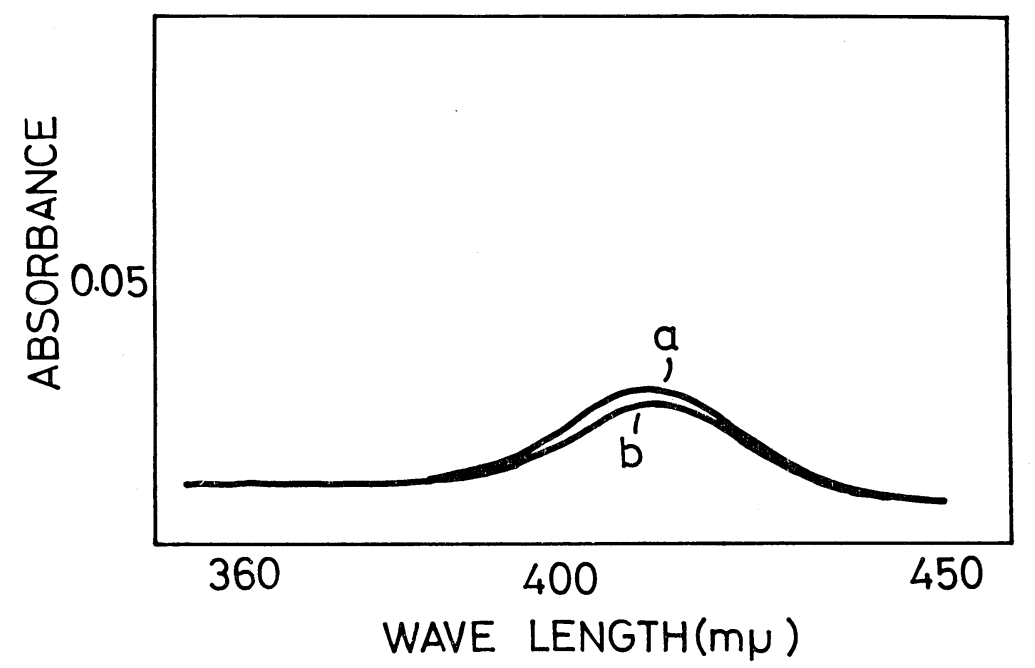

Fig. 17. Molecular weight of hPL-Kobe $\mathrm{hPL}-\mathrm{Kobe}$ in $4 \mathrm{M}$ guanidine- $\mathrm{HCl}$ 25090 r.p.m., $10^{\circ} \mathrm{C}, 60 \mathrm{~min}$.

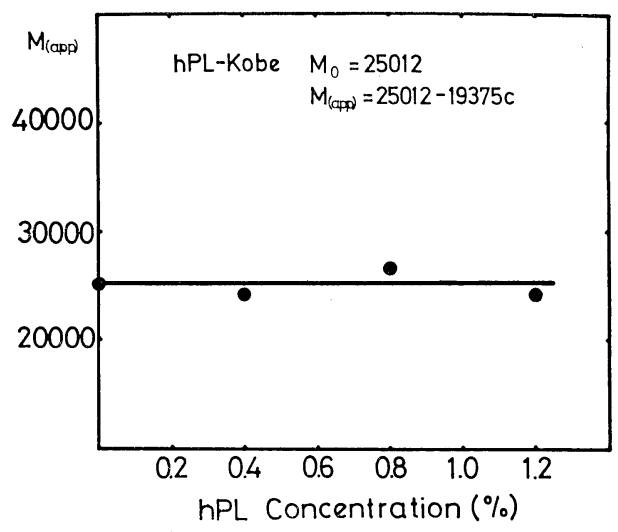


Fig. 19. Absorption spectra of hPL-Kobe modified with 5, 5'-dithiobis (DTNB) in $5 \mathrm{M}$ urea and tris buffer

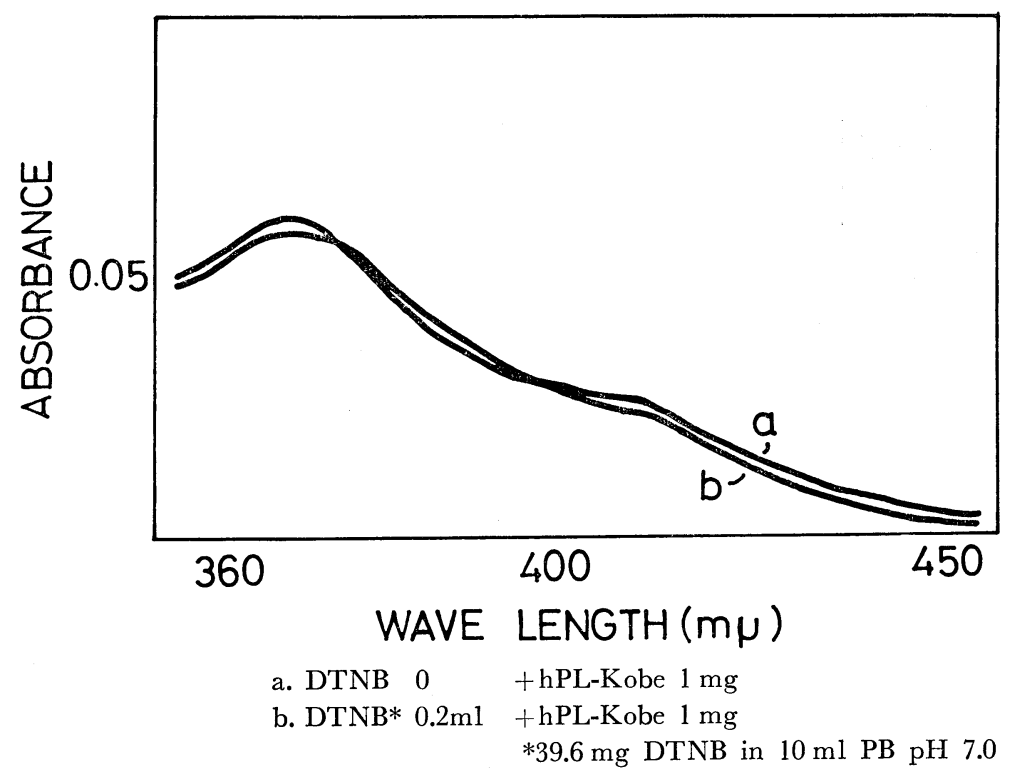

即ち Sherwood ${ }^{17)}$ らは, S-S 結合が生物活性に重要 な意義を持つのであろうと推祭しているが，著者が行 つた実験，つまり分子内の SH 基を carboxymethylation して切断すると，hPL の個有の脂質分解作用が なくなると同時に免疫交叉性も消失したとてろから， 一鎖内 S-S 結合の切断は分子形態をわずか変化させ ただけにすぎないのにもかかわらず，ホルモンとして の性質を全く変化させる程大きな影響を持つている。 従つて hPL の S-S 結合は，活性の発現に必須な条 件であると考えてよいようである.

とてろでポリペプチドホルモン, 特に hGH や $\mathrm{ACTH}^{19)}$ などでは，そのN末端や $\mathrm{C}$ 末端が生物ある いは免疫活性の発現に重要な意義をもつと推論されて いる，hPL に関しては著者の成績によると，LAP に よる $\mathrm{N}$ 末端の切断や粗尿素の $\mathrm{N}$ 末端アミノ酸への作用 によつて（おそらくは混在している cyanate の作用 であろう), hPL-Kobe の生物活性のみが失われ，免 疫活性は保たれていたとてろから，N末端は生物活性 の発現に関与していると思われる。またN末端のアミ ノ酸はバリンであつた。このような成績と ACTH に おける成績を合わせ勘案すると，hPL の免疫活性基 はおそらくN末端に存在すると考えてよいであろう.

一方蛋白体としての hPL の安定性の榆討では, 高
Fig. 20. Absorption spectra of hPL treated with diasonium-1-H-tetrazole(DHT)

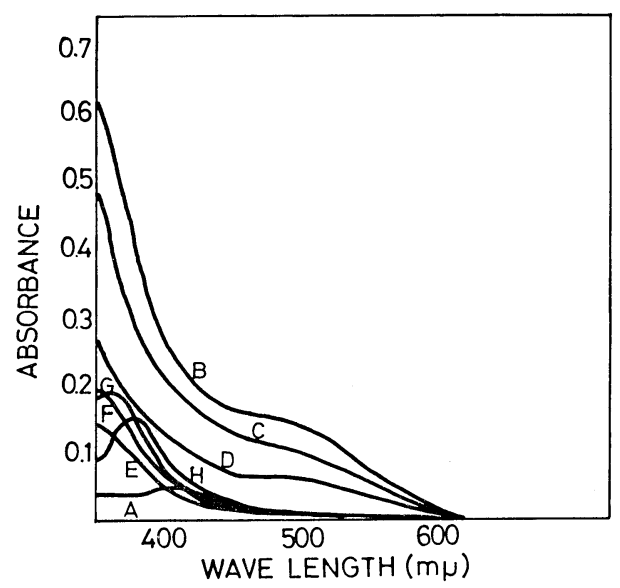

A. hPL in $0.67 \mathrm{M}$ bicarbonate buffer

B. hPL in $0.67 \mathrm{M}$ bicarbonate buffer $+0.01 \mathrm{ml}$ DHT (0min.)

C. hPL in $0.67 \mathrm{M}$ bicarbonate buffer $+0.01 \mathrm{ml}$ DHT (20min.)

D. hPL in $0.67 \mathrm{M}$ bicarbonate buffer $+0.01 \mathrm{ml}$ DHT (40min.)

E. hPL in $5 \mathrm{M}$ urea $+0.025 \mathrm{ml}$ DHT

F. hPL in $5 \mathrm{M}$ urea $+0.05 \mathrm{ml}$ DHT

G. hPL in $5 \mathrm{M}$ urea $+0.075 \mathrm{ml}$ DHT

$\mathrm{H}$. hPL in $5 \mathrm{M}$ urea $+0.175 \mathrm{ml} \mathrm{DHT}$ 
Fig. 21. Rates of reaction between SH-groups of hPL-Kobe and 5, 5'-dithiobis (DTNB)

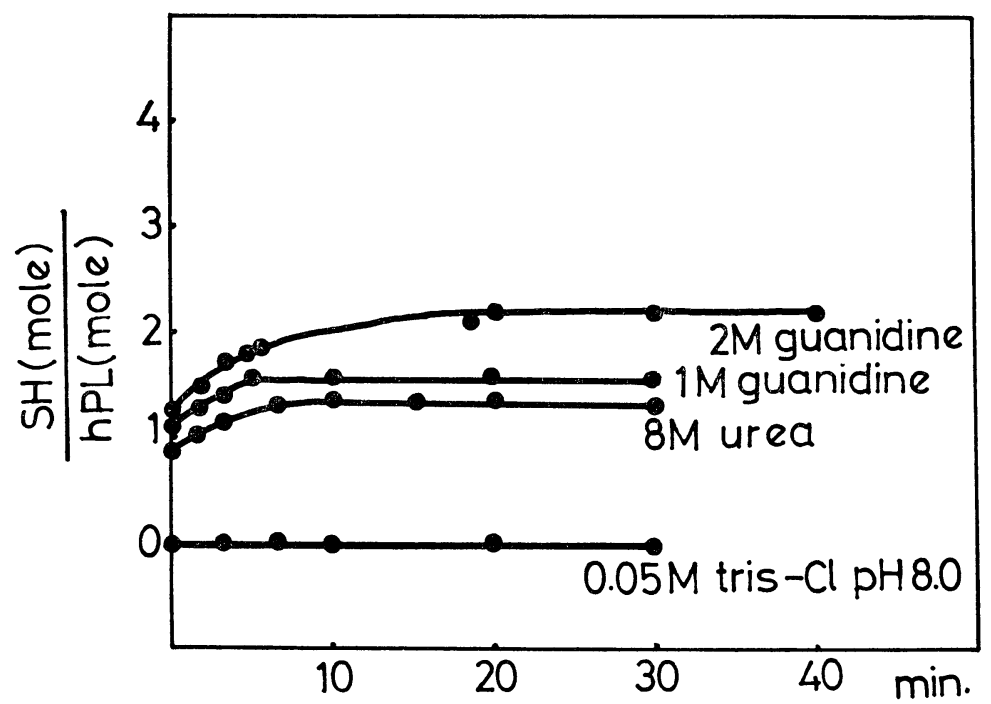

Fig. 22. Gel filtration of hPL on sephadex G-75

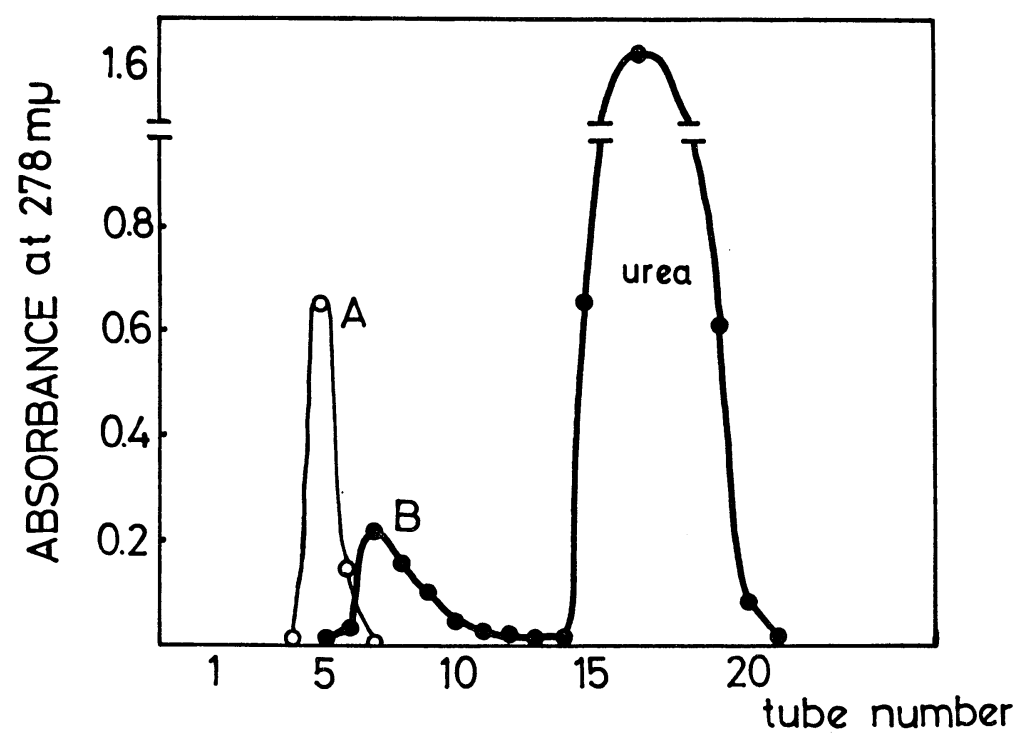

A. hPL $5 \mathrm{mg}$ resolved in $5 \%$ acetic acid

B. hPL $5 \mathrm{mg}$ treated with $8 \mathrm{M}$ urea, reduced with mercaptoethanol and carboxymethylated by $\mathrm{CH}_{2} \mathrm{ICOOH}$

column size $1.0 \times 50(\mathrm{~cm})$, Each effluent volume

$1 \mathrm{ml}$, eluted with $5 \%$ acetic acid 
Table 3. Action of leucin amino peptidase (LAP) at $\mathrm{pH} 8.5$ on the biological activiry of human placental lactogen (hPL)

\begin{tabular}{|c|c|c|c|c|c|}
\hline \multirow{3}{*}{ sample } & \multicolumn{5}{|c|}{ FFA $\mu$ eq per liter } \\
\hline & \multicolumn{5}{|c|}{ incubation time $\left(37^{\circ} \mathrm{C}\right)$} \\
\hline & pre & post & $3 \mathrm{hr}$. & $8 \mathrm{hr}$. & $12 \mathrm{hr}$ \\
\hline Control & $500 \pm 41.6$ & $567 \pm 38.2$ & & & \\
\hline buffer & & $667 \pm 80.5$ & & & \\
\hline hPL + buffer & & & & $950 \pm 50.1$ & \\
\hline $\mathrm{hPL}+\mathrm{LAP}(4 \mu \mathrm{g})$ & & & $700 \pm 51.3$ & $578 \pm 30.1$ & $500 \pm 11.5$ \\
\hline $\mathrm{hPL}+\mathrm{LAP}(40 \mu \mathrm{g})$ & & & $434 \pm 18.9$ & $567 \pm 25.5$ & $500 \pm 15.5$ \\
\hline
\end{tabular}

Fig. 23. Action of leucine aminopeptidase at $\mathrm{pH} 8.5,0.14 \mathrm{M}$ trimethylamine acetate buffer containing $0.002 \mathrm{M} \mathrm{MgCl}_{2}$ on the immunological activity of human placental lactogen

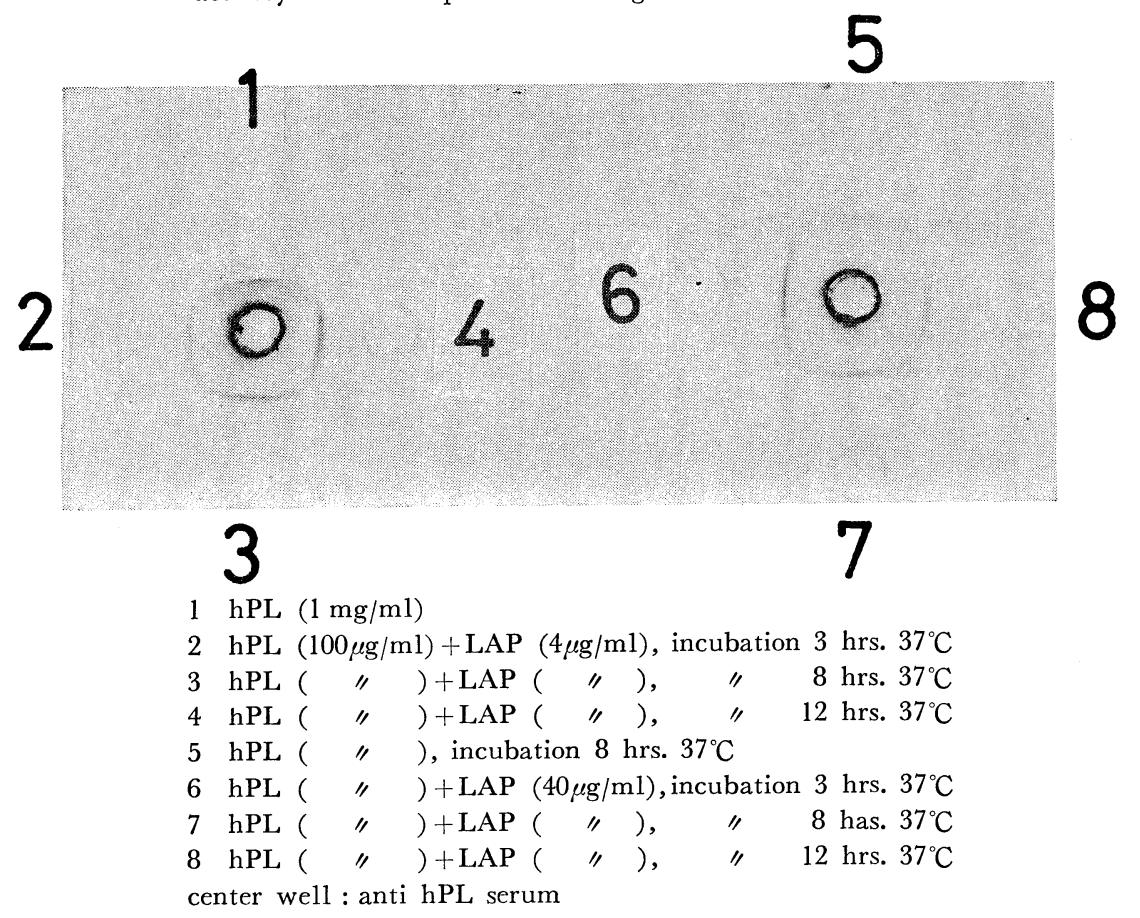

Table 4. Effect of hPL and denatured hPL to the mobilization of FFA ( $\mu$ eq per liter)

\begin{tabular}{c|c}
\hline & average \\
\hline control pre & $600 \pm 23.3$ \\
post & $867 \pm 54.5$ \\
denatured hPL $150 \mu \mathrm{g} / \mathrm{ml}$ & $833.5 \pm 31.5$ \\
none treated hPL $150 \mu \mathrm{g} / \mathrm{ml}$ & $1033.5 \pm 71.7$ \\
\hline
\end{tabular}


温や酸性溶液中で hPL の生物ならびに免疫活性が容易に減弱するとてろから，hPL はきわめて不安定で あろうと考光られる。

つまり第一編でも述べた如く，純化された hPL を採取するためには，酸性溶液での抽出や精製に長時間 かけるととは禁物である．てれまでの諸家の報告をみると，ての点に十分留意しているものは意外と少く， てのようなとてろに hPL の生化学的分析についての 諸家の成績が一定しない原因があると思われる.

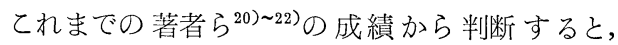
hPL-Kobe は, 「OD $278 \mathrm{~m} \mu$ 亿最大吸光を有し, 酸性 アミノ酸が主体をなす糖を含まない，分子量約 25000 〜26500の単純蛋白体であり，ヒスチジンなぞの塩基 性アミノ酸は遊離の形で存在せず，塩基性溶液では芳 香族アミノ酸は容易にイオン化される傾向を示すし， また SH 残基は遊離の形で存在せず，かつカルボキシ メチレーションによつて S-S 結合を切断しても，化 学的な処置をうけたヒ卜胎盤ラクトーゲンの立体構造 は未処置のそれに比して平担になる傾向を示すのみ で，分子量の変化をきたさない．

したがつて本物質の立体構造の連結や活性部位に関 係するペプタイドは，水素結合よりはもつと結合力の 弱い酸性アミノ酸と塩基性アミノ酸間のイオン化結合 か, 或いは non polar amino acid 間の hydrophobic bonding が主体をなすと考えられ，一鎖ペプタイドの 可能性が強く, ねじれ (helix) の少ない平坦な蛋白構 造をもち，三次構造はおそらく S-S 結合であろう。

また hPL の生物活性はN末端に，免疫活性はおそ らく $\mathrm{C}$ 末端に分かれて存在するように思われ， $\mathrm{pH}$ や 温度などの条件やわずかの立体構造の変化によつて両 活性が消失するから蛋白体としてはきわめて不安定な

Fig. 24. Action of carboxymethylation on the immunocrossreactivity of hPL

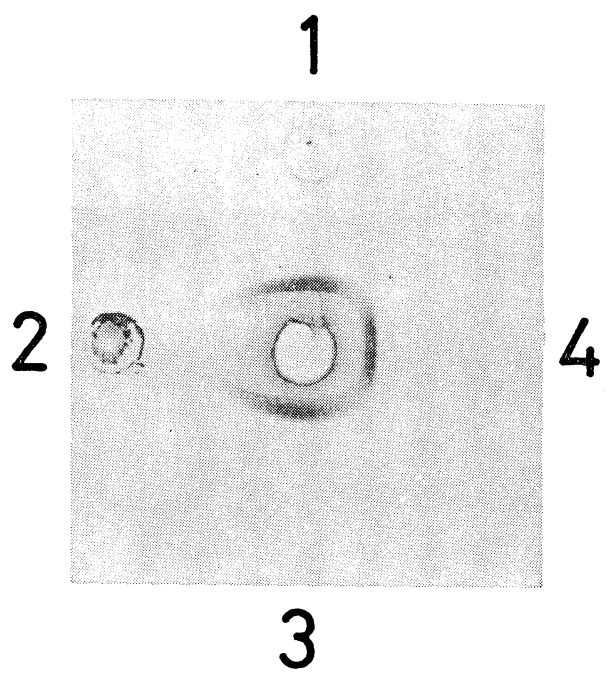

$1 \mathrm{hPL}$ in $5 \%$ acetic acid

2 hPL treated with $8 \mathrm{M}$ urea, reduced by mercaptoethanol and carboxymethylated by $\mathrm{CH}_{2} \mathrm{ICOOH}$

$3 \mathrm{hPL}$ in $4 \mathrm{M}$ urea

$4 \mathrm{hPL}$ in $8 \mathrm{M}$ urea center well : anti hPL serum

'Table 5. Action of urea at $\mathrm{pH} 7.4$ on the biological activity of human placental lactogen (hPL)

\begin{tabular}{|c|c|c|c|c|}
\hline \multirow{2}{*}{ treatment } & \multicolumn{4}{|c|}{ FFA $\mu$ eq per liter } \\
\hline & pre & post & $1 \mathrm{hr}$. & $6 \mathrm{hr}$. \\
\hline control & $567 \pm 31.5$ & $610 \pm 45.0$ & & \\
\hline $2 \mathrm{M}$ commercial urea $+\mathrm{hPL}$ & & & $640 \pm 35.0$ & $610 \pm 40.0$ \\
\hline $2 \mathrm{M}$ recrystallised urea $+\mathrm{hPL}$ & & & $658 \pm 15.0$ & $600 \pm 40.0$ \\
\hline $2 \mathrm{M}$ purified urea $+\mathrm{hPL}$ & & & $940 \pm 65.0$ & $878 \pm 60.0$ \\
\hline $6 \mathrm{M}$ commercial urea $+\mathrm{hPL}$ & & & $580 \pm 30.0$ & $550 \pm 20.0$ \\
\hline $6 \mathrm{M}$ recrystallised urea $+\mathrm{hPL}$ & & & $610 \pm 20.0$ & $590 \pm 40.0$ \\
\hline $6 \mathrm{M}$ purified urea $+\mathrm{hPL}$ & & & $960 \pm 50.0$ & $900 \pm 50.0$ \\
\hline $8 \mathrm{M}$ commercial urea $+\mathrm{hPL}$ & & & $580 \pm 40.0$ & $600 \pm 15.0$ \\
\hline $8 \mathrm{M}$ recrystallised urea $+\mathrm{hPL}$ & & & $580 \pm 50.0$ & $550 \pm 30.0$ \\
\hline $8 \mathrm{M}$ purified urea $+\mathrm{hPL}$ & & & $934 \pm 50.0$ & $850 \pm 50.0$ \\
\hline
\end{tabular}


Fig. 25. Action of urea at $\mathrm{pH} 7.4,0.01 \mathrm{M}$ phosphate buffer on the immunological activity of hPL

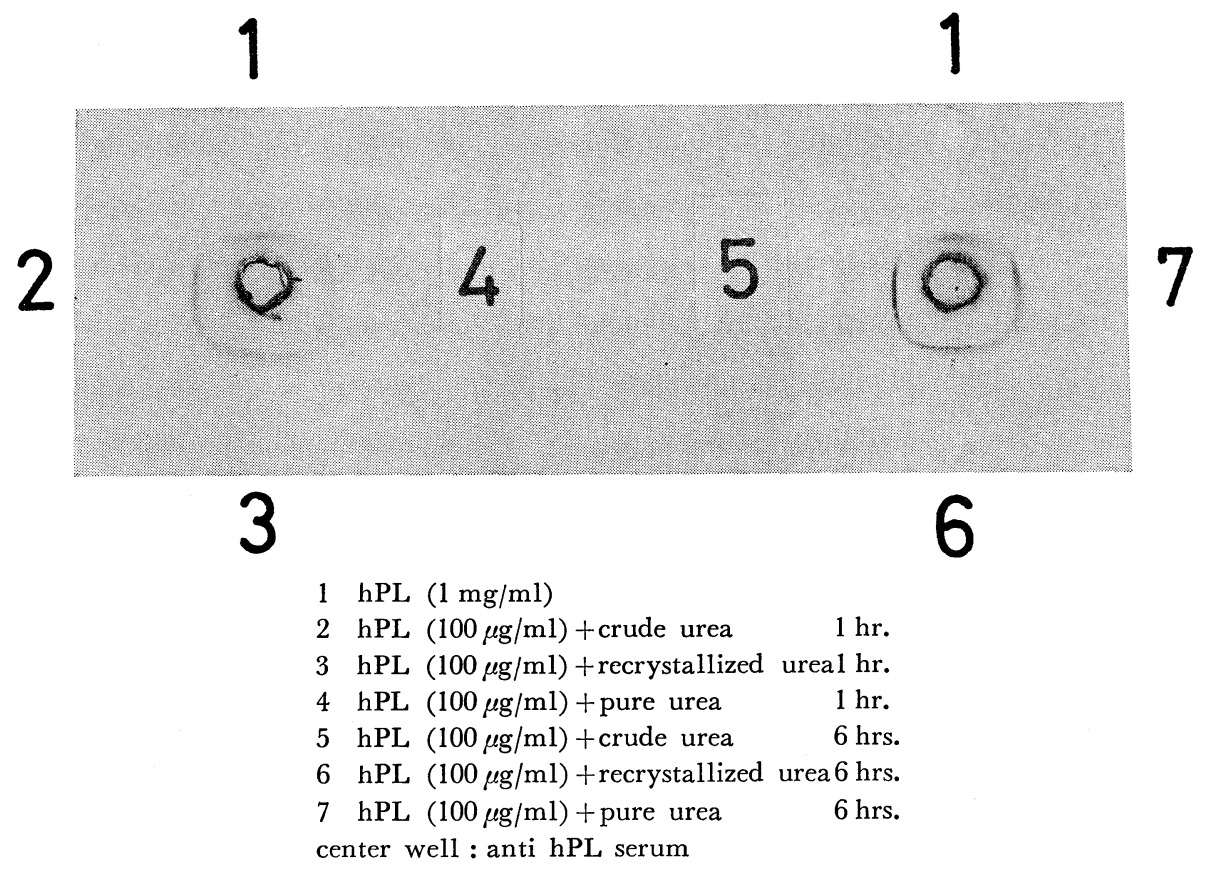

Table 6. Stability of hPL-Kobe after heat treatment in $0.01 \mathrm{M}$ phosphate buffer $\mathrm{pH} 7.4$ for 1 hour

\begin{tabular}{r|c|c|c}
\hline \multirow{2}{*}{ sample } & \multicolumn{3}{|c}{ FFA $\mu$ eq per liter } \\
\cline { 2 - 4 } & pre & post & $1 \mathrm{hr}$. \\
\hline control & $240 \pm 22.5$ & $248 \pm 19.0$ & \\
$\mathrm{hPL} \quad 0^{\circ} \mathrm{C}$ & & & $435 \pm 39.8$ \\
$37^{\circ} \mathrm{C}$ & & & $561 \pm 10.9$ \\
$50^{\circ} \mathrm{C}$ & & & $369 \pm 32.8$ \\
$90^{\circ} \mathrm{C}$ & & & $216 \pm 41.0$ \\
\hline
\end{tabular}

ものであろうと考えられる.

IV 結 語

1.hPL-Kobe の生化学的性格につき検討した.

2. 構成要素の分析では, 酸性アミノ酸が主体をなし, トリプトファンは $0.97 \%$ 含有され, チロジンート リプトファン比は3.26であつた. 糖成分は検出されなかつた.

3. Archibald 法による分子量の検討では, hPL-Kobe は約25000〜26500である.

4. SH 残基, ヒスチジン残基は遊離の形では存在せず，三次結合は S-S 結合であろう.

5. 生物活性はN末端に, 免疫活性はおそらく $\mathrm{G}$ 末端に，それぞれ分離して存在するようである.

6. わずかな条件の変化や立体構造を変えるととによつて, 容易に生物, 免疫活性が消失するとてろから, 
Fig. 26. Stability of hPL-Kobe after heat treatment in $0.01 \mathrm{M}$ phosphate buffer $\mathrm{pH} 7.4$ for 1 hour

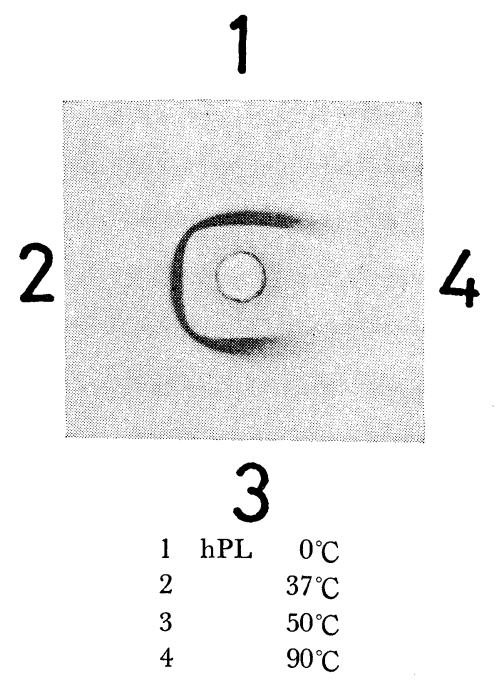

center well : anti hPL serum
Fig. 27. Stability of hPL-Kobe to various $\mathrm{pH}$ at $37^{\circ} \mathrm{C}$ for 1 hour

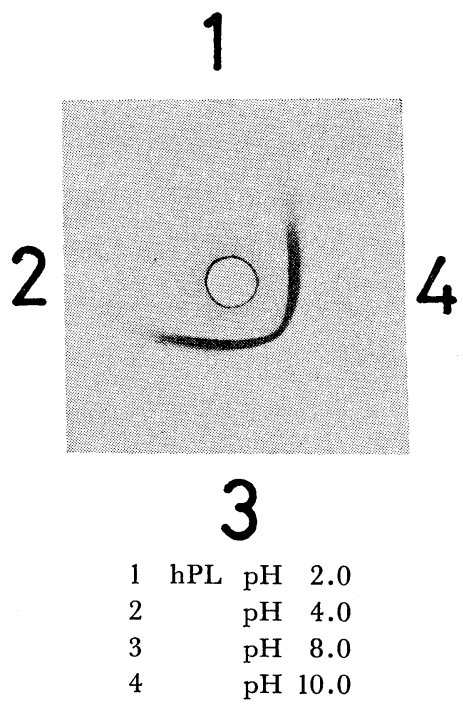

center well : anti hPL serum

Table 7. Stability of hPL-Kobe to various $\mathrm{pH}$ at $37^{\circ} \mathrm{C}$ for 1 hour

\begin{tabular}{ll|c|c|c}
\hline \multirow{2}{*}{ sample } & \multicolumn{3}{|c}{ FFA $\mu$ eq per liter } \\
\cline { 3 - 5 } & & pre & post & $1 \mathrm{hr}$. \\
\hline control & & $230 \pm 16.2$ & $239 \pm 12.2$ & \\
$\mathrm{hPL}$ & $\mathrm{pH} 2.0$ & & & $299 \pm 23.5$ \\
& $\mathrm{pH} 4.0$ & & & $292 \pm 30.3$ \\
& $\mathrm{pH} 8.0$ & & & $775 \pm 35.7$ \\
& $\mathrm{pH} 10.0$ & & & $422 \pm 29.0$ \\
\hline
\end{tabular}

hPL は蛋白体としてきわめて不安定である.

稿を終るに臨み，御指導御校閲をいただいた恩師東条伸平教授に深謝いたします。また終始直接の御指導 御鞭達をいただいた望月真人講師执よび教室の蛋白ホルモングループの諸兄姉に感謝いたします。

本研究の一部は，第 4 回国際内分泌学会で報告した。またアメリカ, N.Y., Rockfeler Universityに括け る特別セミナーで講演した。

\section{参 考 文 献}

1）森川 肇：日内泌誌, $49: 882,(1973) . \quad 2$ 2) Ouchterlony, O. : Acta. Path. Microbiol. Scand., 32 : 231, (1953). $\quad$ 3) Moore, S. and Stein, W.H. : J. Biol. Chem., 192 : 663, (1951).

4) Spande, T.F. and Witkop, B. : Methods in Enzymology, xII, 498, ACADEMIG PRESS, N.Y. and London. $\quad 5)$ Bencze, W.L. and Schmid, K. : Analytical Ghem., 29, (1957). 6) Archibald, W.J. : J. Phys. Ghem., 51 : 1204, (1947). $\quad$ 7) Ellman, G.L. : Arch. Biochem. Biophys., 82 : 70 (1959). $\quad$ 8) Horinishi, H., Hachimori, Y., Kurihara, K., and Shibata, K. : Biochem. Biophys. 
Acta, 86 : 477 (1964).

9) Friesen, H. : Endocrinology, $76: 369$, (1965).

10) Ashitaka, Y. : Acta. Obst. et Gynaec. Jap., $17: 124$, (1970).

11) Ashitaka, Y., Tokura, Y., Tane, M., Mochizuki, M. and Tojo, S. : Endocrinology, 87 : 233 (1970).

12）東条伸平，望月真人，大賀祐

造, 志村利之, 丸尾猛, 西本弘之 : 日内泌誌, 48, 639 (1972).

13) Florini, J.R., Tonelli, G., Breuer, G.B., Coppola, J., Ringler, I. and Bell, P.H. : Endocrinology, 79 : 692, (1966). 14) Li, G.H. and Dixon, J.S. : Arch. Biochem.,146 : 233, (1971). 15) Niall, D., Hogan, M.L., Sauer, R., Rosenblum, I.Y. and Greenwood, F.G. : Proc. Nat. Acad. Sci., 68 : 866, (1971). 16) Neri, P., Arezzini, G., Ganali, G., Gocola, F. and Tarli, P. : Growth and Growth Hormone, Excerpta Medica, AMSTERDAM, (1972). 17) Sherwood, L.M. : Proc. N.A.S., 58 : 2307 , (1967.)

18) Bornstein, J. : Growth and Growth Hormone, Excerpta Medica AMSTERDAM (1972).

19）井村裕夫 : ペプチドホルモン, 朝倉書店, 105, (1973).

20）望月真人, 森川 肇, 椋田 享,

曹 洙鎔, 東条伸平：日産婦誌， $23 ， 450,(1971)$.

21）望月真人, 森川 肇, 岡部桂一郎, 曺洙

鎔, 東条伸平 : 日産婦誌, $23,320,(1971)$.

22) 東条伸平, 望月真人 : 最新医学, 26,1148 ,

(1971). 